\title{
ASSESSING ONLINE LEARNING IN LAW SCHOOLS: STUDENTS SAy ONLINE Classes DELIVER
}

\author{
YVONNE M. DUTTON, ${ }^{\dagger}$ MARGARET RYZNAR ${ }^{\dagger \dagger} \&$ KAYLEIGH LONG ${ }^{\dagger \dagger *}$
}

\begin{abstract}
This Article provides empirical data on the effectiveness of distance education in law schools following the American Bar Association's decision to increase the number of permitted online course credits from fifteen to thirty. Our data, composed of law student surveys and focus groups, reveals not only the success of distance education in legal education, but also the online teaching methods that are most effective for students.
\end{abstract}

\section{TABLE OF CONTENTS}

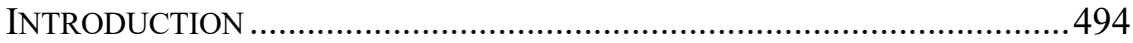

I. THE ABA AND ONLINE LEARNING IN LAW SCHOOLS .......................498

II. TYPES OF ONLINE COURSE OFFERINGS ...........................................502

A. Massive Open Online Courses (MOOCs)...................................503

B. Blended/Hybrid Courses, Including Flipped Classrooms ............506

C. Non-MOOCs Fully Online Courses ..........................................5510

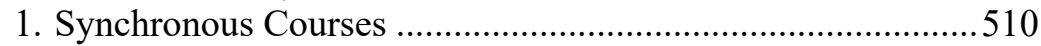

2. Asynchronous Courses …....................................................512

III. RESEARCH DESIGN: THE IU MCKINNEY STUDY ASSESSING

ASYNCHRONOUS ONLINE PROGRAMMING .................................515

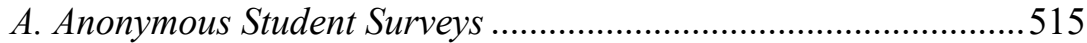

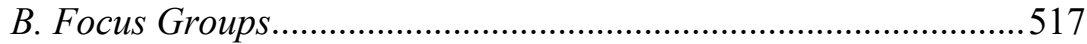

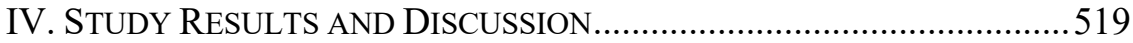

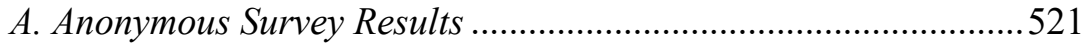

B. Focus Group Results..............................................................522

1. Student Engagement and Learning: Online Versus Live.........522

2. Components of a Quality Online Course .................................525

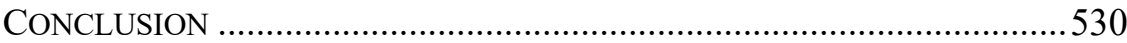

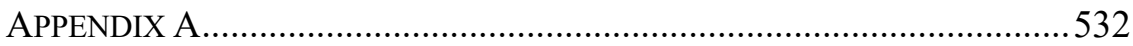

$\begin{aligned} \dagger & \text { Professor of Law, Indiana University Robert H. McKinney School of Law. } \\ \dagger & \text { Professor of Law, Indiana University Robert H. McKinney School of Law. } \\ \text { J.D. 2018, Indiana University Robert H. McKinney School of Law. } & \text { Thanks to Max Huffman for his support as Director of IU McKinney Law Online. Thanks }\end{aligned}$ also to colleagues and the administration of Indiana University McKinney School of Law, including Andy Klein, Mike Pitts, and Antony Page. For course design work and guidance, we are grateful to Zach Carnagey, Anna Lynch, Julia Sanders, as well as the Indiana University-Purdue University Indianapolis (IUPUI) Center for Teaching and Learning and eLearning Design \& Services, University Information Technology Services (UITS). Special thanks to Douglas Jerolimov for advising on and running our focus groups, as well as David Paul and Christina Fisher for supporting our data collection. 


\section{INTRODUCTION}

Law schools in the United States are increasingly embracing the benefits of new technology and meeting student demand for increased flexibility by investing in online education. ${ }^{1}$ As of July 2018, a review of law school websites reveals that at least thirty of the top one hundred schools offer online courses as part of their law school curriculum. ${ }^{2}$ Furthermore, law schools have adopted varying approaches to the incorporation of online learning, offering everything from a fully online law degree ${ }^{3}$ to a handful of online courses. Some schools have created hybrid programs in which coursework is completed online as well as in the classroom. ${ }^{4} \mathrm{Sev}-$ eral of these hybrid programs have even replaced existing evening juris doctor programs (J.D.). ${ }^{5}$ The Authors' law school, Indiana University

1. Flexibility is only one of the benefits to online learning that we discuss below. Flexibility is an important benefit, especially as it can help attract and retain nontraditional students who have family and work demands on their time that might otherwise preclude them from attaining a law degree. See, e.g., Steven C. Bennett, Distance Learning in Law, 38 Seton Hall LegiS. J. 1, 6-7 (2013) (explaining that distance learning can provide flexibility to students who are pursuing a second career and, therefore, have family and work obligations that make a typical legal degree education difficult to pursue).

2. In July 2018, a research assistant searched and examined the website of each of the top 100 law schools ranked by U.S. News and World Report. This covered ranks 1 to 99, including ties. The assistant looked for information on online or hybrid offerings in course listings and program descriptions. A limitation of this approach is that not all law schools may mention their online offerings on their websites, and newly approved or planned online courses may not yet have been added to the websites.

3. For example, Concord Law School has offered a completely online J.D. program since 1999. See Online Juris Doctor Program, CONCORD L. SCH., https://www.concordlawschool.edu/academic-programs/juris-doctor [https://perma.cc/LL74-CVZ7] (last visited Feb. 27, 2019). Other schools, too, offer completely online law degrees. See Distance Learning, AM. HERITAGE U. SCH. L., http://ahulaw.com/distance_learning.php [https://perma.cc/3JF6-XR2X] (last visited Feb. 27, 2019); Introduction to the Juris Doctor (JD Degree), CAL. SOUTHERN U., https://www.calsouthern.edu/online-law-degrees/jd-degree [https://perma.cc/8CXP-X6JJ] (last visited Feb. 27, 2019); Juris Doctor Degree Program, ST. FRANCIS SCH. L., https://stfrancislaw.com/academics/juris-doctor [https://perma.cc/R8PK-WNDU] (last visited Feb. 27, 2019); Juris Doctor Online Law School, ABRAHAM LINCOLN U., https://www.alu.edu/academics/juris-doctor [https://perma.cc/UM9U-JNVB] (last visited Feb. 27, 2019); Part Time Courses, CAL. SCH. L., https://californiaschooloflaw.com/courses [https://perma.cc/L3KB-4NH3] (last visited Feb. 27, 2019). Although such online law schools exist, the ABA has not accredited any of them. Distance Education, A.B.A. (June 19, 2018), https://www.americanbar.org/groups/legal_education/resources/distance_education.html [https://perma.cc/C8UU-SWRT].

4. For example, Loyola University Chicago School of Law's Weekend J.D. program takes a hybrid format where face-to-face instruction occurs only over fourteen weekends in a school year. Weekend JD, LOY. U. CHI., https://www.luc.edu/law/degrees/jurisdoctor-part-time [https://perma.cc/UA6F-7MQV] (last visited Feb. 27, 2019). Touro College Law Center has a FlexTime J.D. program that also uses a hybrid format with a mixture of online and "on-campus classes every other Sunday during the first two years" and then "students will be able to take many courses entirely online during the third and final years." Juris Doctor, TOURO C.: JACOB D. FUCHSBERG L. CTR., https://www.tourolaw.edu/Admissions/juris-doctor [https://perma.cc/YVT8-M94W] (last visited Feb. 27, 2019). In January 2019, Syracuse University College of Law launched ABA-approved JDinteractive, a program with at least $50 \%$ synchronous online instruction and the remainder asynchronous online instruction, combined with some face-to-face courses. JDinteractive: Online J.D. Program, SYRACUSE U.C.L., http://aw.syr.edu/admissions/online-jd-program [https://perma.cc/UA6F-7MQV] (last visited Feb. 27, 2019).

5. Paul Caron, Denver Is the Eighth Law School to Offer a Hybrid J.D., TAXPROF BLOG (Aug. 23, 2018), http://taxprof.typepad.com/taxprof_blog/2018/08/denver-is-eighth-law-school-to-offer-hybrid-jd.html [https://perma.cc/2VDJ-XH4U]. 
Robert H. McKinney School of Law (IU McKinney), is among those embracing online teaching and learning. ${ }^{6}$ As of 2019, IU McKinney offers approximately two-dozen online courses, most created and run by its tenured faculty. ${ }^{7}$

The American Bar Association (ABA) has slowly and steadily shown support for the online movement, proposing in early 2018 to expand the amount of online instruction permitted in law school J.D. programs. ${ }^{8}$ Specifically, based on its "belief that legal education instruction can be delivered as effectively by distance education as by instruction in the traditional manner," the ABA proposed: (1) increasing the total number of credits that law students could earn through asynchronous online classes from fifteen to thirty; and (2) for the first time ever, permitting students to take ten of those credits during their first year of law school. ${ }^{10}$ The ABA adopted this proposal in August 2018, ${ }^{11}$ thus allowing law schools to offer their students the option of taking more online classes in satisfaction of their law degrees. ${ }^{12}$

Despite this trend toward increasing online offerings for law students, few articles assess the effectiveness of teaching and learning in asynchronous courses in the law school environment. ${ }^{13}$ Furthermore, these articles

6. See Online Courses, IND. U. ROBERT H. MCKINNEY SCH. L., https://mckinneylaw.iu.edu/courses/online.cfm [https://perma.cc/CF7T-QN2J] (last visited Feb. 27, 2019).

7. Id.

8. Accredited J.D. programs must abide by ABA standards regarding course content and delivery, including in their delivery of any online or hybrid course offerings. STANDARDS \& RULES OF PROCEDURE FOR APPROVAL OF LAW SCHOOLS Standard 306 (AM. BAR ASS'N 2017-2018), https://www.americanbar.org/content/dam/aba/publications/misc/legal_education/Standards/20172018ABAStandardsforApprovalofLawSchools/2017_2018_aba_standards_rules_approval_law_schools_final.authcheckdam.pdf [https://perma.cc/9G3V-7FFF].

9. Memorandum from Pamela Lysaght, Chair, Am. Bar Ass'n Section of Legal Educ. \& Admissions to the Bar Standards Review Comm., to Maureen O'Rourke, Chair, Council of the Am. Bar Ass'n Section of Legal Educ. \& Admissions to the Bar 4 (Oct. 12, 2017), https://www.americanbar.org/content/dam/aba/administrative/legal education and admissions to the bar/council reports_and_resolutions/November2017CouncilOpenSession/2017_nov_memo_re_proposed_changes_to_standards.authcheckdam.pdf [https://perma.cc/PU3K-JU5A].

10. Memorandum from Maureen A. O'Rourke, Chair, Council of the Am. Bar Ass'n Section of Legal Educ. \& Admissions to the Bar \& Barry A. Currier, Managing Dir. of Accreditation \& Legal Educ., Am. Bar Ass'n, to Interested Persons \& Entities (Feb. 22, 2018), https://www.americanbar.org/content/dam/aba/administrative/legal education and admissions to the bar/council reports_and_resolutions/20180222_notice_and_comment.authcheckdam.pdf [https://perma.cc/5SUDGTB9].

11. Am. Bar Ass'N Section of Legal Educ. \& Admissions to the Bar, Report to the House OF DELEGATES: RESOLUTION 111E, at 5-6 (2018) [hereinafter ABA RESOLUTION 111E].

12. See, e.g., David Frakt \& Carolyn Gachet, Distance Learning: The Future of Legal Education? Part I, FAC. LOUNGE (Apr. 10, 2018), http://www.thefacultylounge.org/2018/04/distance-learning-the-future-of-legal-education.html [https://perma.cc/4JVK-S923] (noting that "it seems inevitable that the ability of law schools to use distance learning will be significantly expanded in the near future"); Karen Sloan, ABA Set to Loosen Restrictions on Online Law Classes, NAT'L L.J. (Feb. 13, 2018, 2:27 PM), https://www.law.com/nationallawjournal/sites/almstaff/2018/02/13/aba-set-toloosen-restrictions-on-online-law-classes [https://perma.cc/3224-ZPR5] (noting that the ABA has progressively relaxed limits on online credits in the past decade).

13. "Asynchronous" course offerings are distinguished from those that are offered "synchronously" online. In the asynchronous course, learning is time-shifted, such that the professor and student need not interact online at the same time. In synchronous courses, the professor and student will 
tend to be "case studies" in which the authors describe their online courses and then make observations and conclusions about the efficacy of online teaching in the law school environment. ${ }^{14}$ These articles generally conclude that online courses have a place in the law school curriculum because they can offer a quality learning experience. ${ }^{15}$

The current literature is only starting to address how students feel about asynchronous online courses. ${ }^{16}$ Do they believe such courses provide a quality learning experience - one that is comparable to quality live classroom learning experiences? What do students conclude constitutes a quality online learning environment where they can master course material as well as the practice skills they will need when they become lawyers? In light of the ABA's new standards regarding online learning, law schools may begin allocating more resources to increase their online offerings, increasing the importance of examining the student experience in these programs. ${ }^{17}$

We do not mean to suggest that law schools should only consider students' opinions when deciding whether to offer online courses or how to design those courses. However, law schools seek student input on other important aspects of the curriculum, including through course evaluations ${ }^{18}$ Furthermore, especially in the online setting, student preferences should contribute to course design because students are responsible for

meet online through a platform such as Skype or Zoom for class meetings. See Henry H. Perritt, Jr., The Internet Is Changing the Face of American Law Schools, 33 IND. L. REV. 253, 269 (1999) (defining "asynchronous" as "time shift[ed]" and "synchronous" as "simultaneous"); see also infra Section II.C.

14. See, e.g., Max Huffman, Online Learning Grows Up — and Heads to Law School, 49 IND. L. REV. 57, 76-84 (2015) (describing his asynchronous online Comparative and International Competition Law course and its use of a course paper and online quizzes, followed by a discussion of common mistakes, as an effective way to ensure comprehension); Susan D. Landrum, Drawing Inspiration from the Flipped Classroom Model: An Integrated Approach to Academic Support for the Academically Underprepared Law Student, 53 DUQ. L. REV. 245, 272-75 (2015) (explaining the creation of an online academic support program for first-year law students through the use of online modules supplemented with live workshops); Kenneth R. Swift, The Seven Principles for Good Practice in [Asynchronous Online] Legal Education, 44 Mitchell HAMLINE L. REV. 105, 111-13, 161 (2018) (describing his asynchronous online Employment Law and Transactional Drafting courses and the ability to more effectively engage in active and cooperative learning and assessment in the online context).

15. See Huffman, supra note 14, at 84 (describing that online courses can deliver content while meeting both student and ABA demands); Landrum, supra note 14, at 276-78 (noting the ability to reach first-year students before they become at risk and the online platform's ability to reuse resources once created); Swift, supra note 14, at 161-62 (explaining the inevitable growth of online legal education and ways to ensure its quality).

16. See Victoria Sutton, Asynchronous, E-Learning in Legal Education: A Comparative Study 6-12 (Aug. 6, 2016) (unpublished manuscript), https://papers.ssrn.com/sol3/papers.cfm?abstract id=2819034 (analyzing student responses to an online law course); see also JENNIFER CAMERO, TEACHING LAW ONLINE 11-21 (2015) (describing how to design an online law course); WORKING GRP. ON DisTANCE LEARNING IN LEGAL EDUC., DisTANCE LEARNING IN LEGAL EDUCATION: DESIGN, DELIVERY AND RECOMMENDED PRACTICES 11, 20, 32 (2015) (compiling best practices on online course design).

17. See supra Introduction.

18. See Arthur Best, Student Evaluations of Law Teaching Work Well: Strongly Agree, Agree, Neutral, Disagree, Strongly Disagree, 38 Sw. L. REv. 1, 1 (2008) (“American law students spend more than 30,000 hours each academic year providing evaluations of their courses."). 
their own learning in an autonomous setting such as an online classroom. ${ }^{19}$ Yet, there is a paucity of literature comprehensively assessing students' perceptions of online learning in the law school context.

At this important juncture, where the trend is toward increasing online offerings in law schools, this Article fills an important void-sharing the results of a study that assesses the quality of asynchronous online teaching and learning in the law school context using student perceptions. Our data, gathered from students who have taken online courses at IU McKinney, supports the conclusion that students not only want more online offerings, but also that online classes can deliver the same quality learning experience as live classes. Specifically, the data reveals several key conclusions. First, students appreciate an online course that is organized in the way it presents material and assignments. Second, students equate a quality course with one that engages students with course content-for example, through short, focused, and interesting lectures, or through YouTube videos and other media that relate to course content. Third, students associate quality courses with those that involve regular assessment (especially practice-ready assignments) and professor feedback.

We do not mean to suggest that all law students will perceive all online courses as comparable to their live courses in delivering a quality teaching and learning experience. That conclusion is overly broad. First, some students simply may not enjoy learning through an online platform or interacting with technology in this setting. ${ }^{20}$ Second, some online courses may not appeal to students who are generally receptive to the online learning environment. ${ }^{21}$ Finally, some self-disciplined students who have well-developed time-management skills may self-select into online courses, thus increasing the likelihood that feedback regarding online courses will be positive. ${ }^{22}$

The online teaching and learning environment is a unique one, requiring the professor to capture students' attention remotely. This fact alone

19. Cassandra L. Hill, The Elephant in the Law School Assessment Room: The Role of Student Responsibility and Motivating Our Students to Learn, 56 How. L.J. 447, 450-51 (2013).

20. See infra Part IV.

21. See infra Part IV.

22. Much literature suggests that students with high levels of self-regulation and discipline are most likely to succeed in the online environment, where they must self-direct their learning process. See Anthony R. Artino Jr. \& Jason M. Stephens, Academic Motivation and Self-Regulation: A Comparative Analysis of Undergraduate and Graduate Students Learning Online, 12 INTERNET \& HIGHER EDUC. 146, 149 (2009) (finding that graduate students were less likely to procrastinate in online courses, a characteristic of self-regulation); Lucy Barnard et al., Online Self-Regulatory Learning Behaviors as a Mediator in the Relationship Between Online Course Perceptions with Achievement, INT'L REV. RES. OPEN \& DISTANCE LEARNING, June 2008, at 8 (explaining that self-regulation accounts for a "positive relationship between student perceptions of online course communication and collaboration with academic achievement"); Richard Lynch \& Myron Dembo, The Relationship Between Self-Regulation and Online Learning in a Blended Learning Context, INT'L REV. RES. OPEN \& DistANCE LEARNING, August 2004, at 10-12 (conducting a study that found a positive relationship "between self-efficacy and performance in online education"). 
means that professors must use unique teaching tools. The data shows that students value an online course that takes this reality into account. ${ }^{23}$ For an online course to succeed in delivering a quality teaching and learning experience, the professor must also create an online course that is organized, engaging, and provides opportunities for students to receive feedback on activities that allow them to assess their learning of the material and practice real-world skills.

As we predict that law schools will offer increased opportunities for online learning, we anticipate that administrations and faculty will be interested in what students say makes an online legal course beneficial both academically and practically. Accordingly, Part I of this Article begins by detailing the evolution of online learning in law schools, focusing especially on the role that the ABA plays in regulating the delivery of online course content to law students. Part II continues by explaining the different types of online classes and discussing some of the perceived advantages or disadvantages of each type in terms of student engagement and learning. This Part explains the different types so that readers are able to understand the nature of an asynchronous course in the context of the other types of online course offerings. From this Part, readers will also be able to compare the advantages and disadvantages of asynchronous courses to the other types of online offerings. In Part III, we explain our research design. In Part IV, we discuss the results of our study that include data from anonymous student surveys and focus group sessions. As noted above, the findings show that students in our study value online courses, want more of them, and point to many features of online courses that make them comparable to live classes in terms of delivering a quality learning experience. ${ }^{24} \mathrm{We}$ conclude by providing observations about our findings and suggestions for law school professors and administrators as they consider increasing their online academic presence.

\section{THE ABA AND ONLINE LEARNING IN LAW SCHOOLS}

Law schools have been slower than their undergraduate and graduate counterparts to incorporate online education into their J.D. academic programs. ${ }^{25}$ Two overarching reasons explain this phenomenon. First, law schools have operated according to one model for more than a century: the face-to-face course where "students prepare for class by reading assigned

\footnotetext{
23. See infra Part IV.

24. See infra Part IV.

25. Linda Harasim, Shift Happens: Online Education as a New Paradigm in Learning, 3 INTERNET \& HIGHER EDUC. 41, 43 (2000) (stating that the first online undergraduate courses were offered through the program Virtual Classroom in 1984, and the first online graduate courses were offered through Nova Southeastern University, Connect-Ed, and the University of Toronto in 1985). The first online law school courses were offered in the 1997-1998 school year after the ABA's Accreditation Committee passed the Temporary Guidelines on Distance Learning, which first allowed law schools to offer online courses. See Laura N. Gasaway, Distance Learning Survey, SYllabus, Summer 1998, at 16, 16.
} 
texts or completing other assignments, then attend class where the teacher leads a Socratic dialogue, facilitates a discussion, or presents a lecture." ${ }^{26}$ Like all institutions that have a traditional way of doing things, law schools are resistant to change. ${ }^{27}$ Thus, this adherence to the traditional law school curriculum has stymied the incorporation of online learning in law schools. Second, accredited law schools must abide by the standards advanced by their governing body, the ABA. ${ }^{28}$ Given that the ABA wants to ensure that law schools produce well-trained lawyers, it has necessarily taken a cautious approach toward introducing online teaching and learning into the law school curriculum. ${ }^{29}$

However, the ABA has started to accept the idea of online course offerings. In 1997, the ABA made its first move toward allowing online education by approving temporary guidelines that allowed law schools to include online courses in their J.D. programs. ${ }^{30}$ The allowed programming was limited and excluded asynchronous course offerings. ${ }^{31}$ In 1999, commentators at the Distance Education Conference expressed concerns about online law school courses, questioning the number of distance courses that schools could offer and whether courses should be synchronous or asynchronous. ${ }^{32}$

26. Gerald F. Hess, Blended Courses in Law School: The Best of Online and Face-to-Face Learning?, 45 MCGEORGE L. REV. 51, 52 (2013).

27. See Bennett, supra note 1, at 2-3 (noting that law schools and the ABA have been committed to the Socratic method at the expense of adopting distance learning); Abigail Cahak, Beyond Brickand-Mortar: How (Cautiously) Embracing Internet Law Schools Can Help Bridge the Legal Access Gap, 2012 U. ILL. J.L. TECH. \& POL'Y 495, 497, 507-09 (2012) (explaining that the ABA appears to believe that online law schools cannot provide a satisfactory education); Huffman, supra note 14, at 57 (stating that the ABA has remained committed to the traditional Socratic classroom and has therefore limited law schools' ability to offer online courses and degrees).

28. About Us, A.B.A., https://www.americanbar.org/groups/legal_education/about_us.html [https://perma.cc/WDV4-S2RZ] (last visited Feb. 27, 2019) (stating that the ABA's Section of Legal Education and Admissions to the Bar is responsible for the national accreditation of schools with J.D. programs and all fifty states permit graduates of ABA-accredited law schools to sit for their bar examinations).

29. Am. Bar Ass'n Section of Legal Educ. \& Admissions to the Bar, Temporary Distance Education Guidelines, SYLLABUS, Fall 1997, at 12, 12 [hereinafter ABA Temporary Distance Guidelines] (noting that law schools must be ready to implement new technologies, but also cautioning that "[e]ducating a student for a Juris Doctor degree is professional education of a most distinct variety"); Gasaway, supra note 25 (noting law school concerns that online courses preserve quality, pedagogical soundness, and faculty-student interaction); Randall T. Shepard, From the Chair: Our Evolving Policy on Distance Learning, SYLlabus, Winter 1999, at 5, 5 (noting that the ABA's policy at the time affirmed "that the term distance learning is not a talisman in the presence of which everyone may stop thinking about the caliber of the education being provided").

30. ABA Temporary Distance Guidelines, supra note 29, at 12-13.

31. Id. at 13 (stating that "delivery to a site that merely has technical personnel to operate and maintain educational or transmission equipment, but does not have a law faculty, is not in compliance with the above principles").

32. Am. Bar Ass'n Section of Legal Educ. \& Admissions to the Bar, Distance Education Conference, SYLLABUS, Fall 1999, at 1, 1, 5. 
By 2002, the ABA proposed permanent regulations regarding online education in the form of Standard 306 in the ABA's Standards for Approval of Law Schools. ${ }^{33}$ In issuing Standard 306, the ABA emphasized that legal education "can include a healthy dose of distance education at schools that are willing to invest the time, talent, and resources to make it work well." ${ }^{34}$ As originally adopted, the Standard allowed for synchronous and asynchronous courses, but limited law students to taking no more than four online credits in one term and no more than twelve credits throughout their enrollment. ${ }^{35}$ Furthermore, this Standard only allowed students to take distance education courses after they had completed twenty-eight credits, which equates to the first year of law school. ${ }^{36}$ The ABA also made clear that not all online course offerings would satisfy Standard $306 .{ }^{37}$ To meet this Standard, both synchronous and asynchronous courses had to give students "opportunities to interact with instructors that equal or exceed the opportunities for such interaction with instructors in a traditional classroom setting." 38 The ABA did not define the term "interaction," but did make clear that law schools would have to be rigorous in delivering an interactive environment. ${ }^{39}$

As technology continued to develop, and as more law professors delivered courses via online platforms, legal educators began to accept that students could receive quality legal education through distance courses. ${ }^{40}$ By 2010, thirty-seven law schools offered synchronous courses, and forty law schools offered asynchronous courses. ${ }^{41}$ In 2014, the ABA updated Standard 306 to allow J.D. students to take up to fifteen credit hours of online courses during their enrollment, ${ }^{42}$ but gave no explanation for why the ABA thought an increase was necessary or permissible. ${ }^{43}$ However,

33. Am. Bar Ass'n Section of Legal Educ. \& Admissions to the Bar, Proposed Revisions to Standards 304 and 305 and a Proposed New Standard Regarding Distance Education, SYLLABUS, Feb. 2002, at 7, 7 [hereinafter ABA Proposed Revisions to 304 and 305]. The proposed revisions were approved by the Council of the Section on Legal Education and Admissions to the Bar. Am. Bar Ass'n Section of Legal Educ. \& Admissions to the Bar, Revisions to the Standards and Interpretations Approved by the Council of the Section: June 2002, A.B.A. J., Aug. 2002, at 77, 77.

34. ABA Proposed Revisions to 304 and 305, supra note 33.

35. Id. at 10 .

36. Id.

37. See id.

38. Id. at 11 .

39. See Interpretation 306-4 in ABA Proposed Revisions to 304 and 305, supra note 33, at 11, which dictates the cited interaction standard but does not explain exactly what that interaction should be. The other Interpretations listed for Standard 306 do not provide clarification. See id. at 10-11.

40. William R. Rakes, From the Chairperson: Distance Education, Syllabus, Winter 2007, at 2, 2-3 (quoting the then-Dean of Nova Southeastern University, Joseph Harbaugh, as stating that law school professors had "concluded that they c[ould] achieve virtually all of the pedagogical goals of a face-to-face classroom using [distance education] technology")

41. Hess, supra note 26, at 53-54.

42. AM. BAR AsS'N SECTION OF LEgAl EduC. \& AdMisSIONS to the BAR, REPORT TO THE House of DELEGATES: RESOlution 103A: REVISED STANDARDS FOR APPROVAL OF LAW SCHOOLS 30-31 (2014) [hereinafter ABA RESOLUTION 103A].

43. Am. Bar Ass'n Section of Legal Educ. and Admissions to the Bar, Chapter 3: Explanation of Changes, in COMPREHENSIVE REVIEW OF THE ABA STANDARDS FOR APPROVAL OF LAW SCHOOL 
under this new standard, the ABA still prohibited students from taking online courses until they had completed at least twenty-eight credit hours. $^{44}$

Most recently, in October 2017, the ABA announced a proposal to expand the amount of online instruction permitted in law schools based on its "belief that legal education instruction can be delivered as effectively by distance education as by instruction in the traditional manner." 45 It accompanied this proposed expansion with a call for a "measured transition" that would permit "continued evaluation of the effectiveness of distance education in the legal education context and developing confidence in the effectiveness of distance education by bar admissions authorities." ${ }^{46}$ In early 2018, the ABA made its proposed amendment to Standard 306 available for comment. ${ }^{47}$

Under the new standard, students could earn up to one-third of their total J.D. credit hours online, and ten of those credits could be earned during the first year. ${ }^{48}$ The ABA defines an online course as "one in which students are separated from the faculty member or each other for more than one-third of the instruction and the instruction involves the use of technology to support regular and substantive interaction among students and between the students and the faculty member, either synchronously or asynchronously.",49

The amended Standard 306 would place limits on the amount of online credit hours J.D. students could accrue. Furthermore, under the amended Standard 306, an online course must be "approved as part of the school's regular curriculum approval process" with "opportunity for regular and substantive interaction between [the] faculty member and student and among students; [and] . . regular monitoring of student effort by the faculty member and opportunity for communication about that effort." Finally, the course must comply with Standard 306's learning outcomes requirements, which emphasize competency in areas such as knowledge

MATTERS FOR NOTICE AND COMMENT (2013), https://www.americanbar.org/content/dam/aba/administrative/legal_education_and_admissions_to_the_bar/council_reports_and_resolutions/20130906_notice_comment_chs_1_3_4_s203b_s603d.authcheckdam.pdf [https://perma.cc/BR22-3PV7].

44. ABA ReSOLUTION 103A, supra note 42, at 31.

45. Lysaght, supra note 9.

46. Id.

47. Notices of Proposed Standards Changes and Responses to Proposed Standards Changes: Notice and Comment, A.B.A. (June 19, 2018), https://www.americanbar.org/groups/legal_education/resources/notice_and_comment [https://perma.cc/2S5S-DBR3] (last visited Feb. 27, 2019).

48. O'Rourke \& Currier, supra note 10.

49. STANDARDS \& RULES OF PROCEDURE FOR APPROVAl of LAW SCHOOLS Standard 306 (AM. BAR ASS'N 2017-2018), https://www.americanbar.org/content/dam/aba/publications/misc/legal_education/Standards/2017-2018ABAStandardsforApprovalofLawSchools/2017_2018_aba_standards_rules_approval_law_schools_final.authcheckdam.pdf_https://perma.cc/9G3V-7FFF].

50. Id. 
of the law, legal analysis and reasoning, professional responsibility, and other legal skills the law school may find appropriate. ${ }^{51}$

The Standard 306 proposal received one comment, from Vermont Law School, which supported the increase in permissible online credit hours and noted that the increase would "attract more non-traditional students who otherwise could not commit to three years of study away from family, community, or other professional obligations." 52 On May 11, 2018, the ABA's Standards Review Committee gave no further recommendations on the proposals to update Standard 306. ${ }^{53}$ In August 2018, the $\mathrm{ABA}$ adopted the proposal to allow law students to take the equivalent of a full year of classes online. ${ }^{54}$

In sum, over the past twenty years, there has been a significant change in the acceptability of online learning in law schools. As of 2018, the ABA is much more comfortable with online legal education because of law school experimentation with online teaching and learning, which delivered positive results. This overall shift, combined with the prospect that even more law schools will be offering online courses after the ABA's passage of the 2018 Standard, makes studies like the one presented in this Article more relevant than ever. Law schools and law professors need to ensure that they are delivering quality online courses that engage students and encourage them to master the course content and the skills that they need to practice law. ${ }^{55}$

\section{TYPES OF ONLINE COURSE OFFERINGS}

Universities and law schools have traditionally delivered classes to their students through the face-to-face classroom setting. ${ }^{56}$ Yet, distance education has a long history. The University of Chicago first pioneered distance education in 1892, almost a century before the Internet became publicly available, by mailing course materials to students and employing

\footnotetext{
51. Id.

52. Letter from Thomas McHenry, President \& Dean, Vt. Law Sch., to Maureen A. O'Rourke, Chair, Council of the Am. Bar Ass'n Section of Legal Educ. \& Admissions to the Bar 1-2 (Mar. 27, 2018), https://www.americanbar.org/content/dam/aba/administrative/legal_education_and_admissions_to_the_bar/council_reports_and_resolutions/comments/20180327_comment_s306_vermont_law_school.authcheckdam.pdf [https://perma.cc/3KZA-HZ8H].

53. Am. BAR Ass'N Section of Legal Educ. AND AdMissions to the Bar, COUNCIL MEETING, OPEN SESSION 2-3 (May 11, 2018), https://www.americanbar.org/content/dam/aba/administrative/legal_education_and_admissions_to_the_bar/council_reports_and_resolutions/August20180penSessionMaterials/18_may_council_open_session_minutes.authcheckdam.pdf [https://perma.cc/7Q9S-BVRY].

54. ABA RESOLUTION 111E, supra note 11.

55. See Huffman, supra note 14, at 66; see also supra note 33 and accompanying text.

56. Alex Berrio Matamoros, Answering the Call: Flipping the Classroom to Prepare PracticeReady Attorneys, 43 CAP. U. L. REV. 113, 116 (2015) ("Until the advent of online learning, the lecture, discussion, and coaching components all required face-to-face interactions between [law] students and instructors, usually during class time or office hours."); Andrea L. Porter et al., Comparison of Online Versus Classroom Delivery of an Immunization Elective Course, 78 AM. J. PHARMACEUTICAL EdUC., Article 96, at 1 (2014) ("[T] he classroom has been the standard venue for delivering information to students.").
} 
traveling lecturers. ${ }^{57}$ The reasons that motivated the University of Chicago to incorporate distance learning into its curriculum, such as a desire to increase access to education, withstood the passage of time and fueled modern-day distance education. ${ }^{58}$ Since that time, online courses have developed in various forms as computer and Internet technology has evolved. ${ }^{59}$

As defined by the ABA, online classes are those that are distance ${ }^{60}$ for more than one-third of the instruction time. ${ }^{61}$ Hybrid classes are those that are distance for one-third or less of total instruction time. ${ }^{62}$ Online and hybrid classes can further be defined by their method of content delivery, such as whether content is provided via asynchronous or synchronous means. ${ }^{63}$

This Part discusses how each type of nontraditional course is administered, including the role of the professor and students, the types of assessments administered, and the level of interaction between instructor and student. This Part also discusses the benefits and detriments of each form of online course - from the perspective of both the student and the professor. Finally, this Part examines the different methods that online courses use to deliver content, either synchronously or asynchronously.

\section{A. Massive Open Online Courses (MOOCs)}

Although no law school currently offers credit for this type of course, massive open online courses (MOOCs) constitute a form of a fully online curriculum that is "built around pre-recorded video presentations, often by

57. Breakthroughs: 1890s, U. CHI., https://www.uchicago.edu/breakthroughs/1890s [https://perma.cc/H69L-FFAU] (last visited Feb. 27, 2019); see also Jenna Hentoff, Compulsory Licensing of Musical Works in the Digital Age: Why the Current Process Is Ineffective \& How Congress Is Attempting to Fix It, 8 J. HIGH TECH. L. 113, 120-21 (2008) (noting that the Internet became publicly available in the early 1990 s).

58. Breakthroughs: 1890s, supra note 57.

59. See, e.g., David Ferrer, History of Online Education, QUAD, https://thebestschools.org/magazine/online-education-history [https://perma.cc/4RMG-HYZB] (last visited Feb. 27, 2019); see also Harasim, supra note 25, at 44-45 (describing the technological advances beginning in the 1970s that make online education in general possible, including educational use of computer networking beginning in the 1970s, the first online courses and the increased access to computers and networks in the 1980 s, and the rise of national educational networking programs in the 1990s).

60. STANDARDS \& RULES OF PROCEDURE FOR APPROVAL OF LAW SCHOOLS Standard 306 (AM. BAR ASS'N 2017-2018), https://www.americanbar.org/content/dam/aba/publications/misc/legal_education/Standards/2017-2018ABAStandardsforApprovalofLawSchools/2017_2018_aba_standards_rules_approval_law_schools_final.authcheckdam.pdf [https://perma.cc/9G3V-7FFF] (“A distance education course is one in which students are separated from the faculty member or each other ....").

61. Huffman, supra note 14 , at 66 .

62. $I d$. at 66 n. 71 .

63. Id. at $58-59$. 
professors who are famous in their fields, which may incorporate still images, audio recordings, or other videos. ${ }^{" 64}$ Any person with an Internet connection can access most MOOCs without cost. ${ }^{65}$ However, some MOOCs do require payment and, in exchange, the participant can receive a certificate of completion. ${ }^{66}$ In all MOOCs, enrollment is essentially unlimited. ${ }^{67}$

Although the term MOOCs was coined in $2008,{ }^{68}$ this course format did not gain prominence until 2012, when two Stanford University computer science professors launched the for-profit company Coursera. ${ }^{69}$ Most MOOC offerings were initially limited to the science and technology fields $;{ }^{70}$ however, MOOC courses now offer instruction in additional fields, including art, design, food and nutrition, history, law, and philosophy. ${ }^{71}$ At the end of 2012, there were over two million registrations on Coursera, and "[b]y May 2013, Coursera was offering 370 different courses, and it had signed partnership agreements with thirty-three universities, including Princeton, Brown, and Columbia." ${ }^{72}$ Coursera now touts thirty-three million enrollments, partnerships with over 150 universities, over 2,700 courses, and at least 4 degree programs. ${ }^{73}$ Expanding the market, Massachusetts Institute of Technology and Harvard University launched the nonprofit platform edX.$^{74} \mathrm{EdX}$ currently partners with over 120 institutions $^{75}$ and offers over 2,100 courses. $^{76}$

MOOCs have "a syllabus, and course content typically consists of readings, assignments, and lectures, which are often short (6-12 minutes) 'microlectures.", 77 Many professors post online the same content that they

64. Philip G. Schrag, MOOCs and Legal Education: Valuable Innovation or Looming Disaster?, 59 VILL. L. REV. 83, 85 (2014).

65. MITx on edX (MOOCs), MIT OPEN LEARNING, https://openlearning.mit.edu/beyond-campus/mitx-edx-moocs [https://perma.cc/5ZUU-YC7] (last visited Apr. 10, 2019).

66. Id.

67. Laura Pappano, The Year of the MOOC, N.Y. TIMES (Nov. 2, 2012), https://www.nytimes.com/2012/11/04/education/edlife/massive-open-online-courses-are-multiplying-at-a-rapidpace.html [https://perma.cc/5JD8-2GS9].

68. I. Elaine Allen \& JefF Seaman, Changing Course: Ten Years of Tracking OnLine Education IN the United STATES 8 (2013); see also Jeffrey A. Van Detta, The Law School of the Future: How the Synergies of Convergence Will Transform the Very Notion of "Law Schools" During the 21st Century from "Places" to "Platforms," 37 U. LA VERNE L. REV. 103, 118 (2015) ("MOOCs started in 2008.").

69. Schrag, supra note 64 , at 85-86.

70. Id. at 88 .

71. Courses, EDX, https://www.edx.org/course?course=all [https://perma.cc/9NRS-X6XR] (last visited Feb. 27, 2019).

72. Schrag, supra note 64 , at 87.

73. About, COURSERA, https://about.coursera.org [https://perma.cc/SZ3Z-6RMN] (last visited Feb. 27, 2019).

74. About edX, EDX, https://www.edx.org/about-us [https://perma.cc/2ZLK-Y9NH] (last visited Feb. 27, 2019).

75. Id.

76. See, e.g., Courses, supra note 71.

77. MOOCS II, EDUCAUSE, 7 ThINGS You Should KNOW ABOUT ... (June 2013), https://library.educause.edu/-/media/files/library/2013/6/eli7097-pdf.pdf [https://perma.cc/DA4W-S46B]. 
are presenting live at their home universities, so their initial burden in creating a MOOC is relatively small. ${ }^{78}$ Students then follow the dictates of the syllabus, which involves reading class materials, watching lectures, "participat[ing] in online discussions and forums, and complet[ing] quizzes and tests on the course material." 79 However, professors in MOOCs face a large burden in terms of student interaction and grading. ${ }^{80}$ It is difficult for them to provide students with direct feedback given the potentially thousands of students participating in the course. ${ }^{81}$ Thus, professors may opt to have teaching assistants monitor student work and respond to student questions on discussion boards. ${ }^{82}$ If an assignment or exam cannot be graded automatically through a computer, the professor may also rely on peer grading with several students grading the same assignment. ${ }^{83}$

MOOCs are beneficial for students because prerecorded lectures provide students access to course content anywhere and at anytime. ${ }^{84}$ Additionally, because many MOOCs are free or low cost, they attract students with a wide array of interests, from "informal learning, competency in a particular area ..., and, in some cases, credit toward a formal degree or certification program. ${ }^{" 85}$ Finally, if assignments are computer graded, students can get their results and feedback instantaneously. ${ }^{86}$ For professors, MOOCs can be beneficial because they "encourage institutions to seek partnerships and collaborations" and have become "a kind of workspace or lab for innovation, helping uncover new best practices that can be used in other online, blended, or face-to-face settings." ${ }^{, 87}$

While the low-to-no cost, unlimited-enrollment online model makes higher education more accessible to all, it also contributes to the inherent disadvantages of MOOCs. As described above, while launching MOOCs might be relatively easy for professors, difficulties arise when they must interact with, and grade the work of, potentially thousands of enrollees. Students may not receive adequate, or any, interaction with the professors. Instead, students must seek out peer-to-peer interaction, and might have varying degrees of success. ${ }^{88}$ For example, differences in students' interest

\footnotetext{
78. Pappano, supra note 67.

79. MOOCS II, supra note 77.

80. Pappano, supra note 67.

81. Id.

82. Id.

83. Id.

84. Id.

85. MOOCS II, supra note 77

86. Celeste Hammond et al., Online Learning and Transactional Skills Courses, 18 TRANSACTIONS TENN. J. BUS. L. 521, 524 (2016).

87. MOOCS II, supra note 77.

88. See, e.g., Pappano, supra note 67 (comparing a MOOC student who arranged a meet up with other MOOC students and no one showed up against another MOOC student who met up weekly with a study group and who noted that she had only completed MOOCs in which she had a study group).
} 
and motivation determine the value and accuracy of their feedback to peers. $^{89}$

Further, MOOCs are known for their staggeringly low completion rates. ${ }^{90}$ For example, free MOOCs at edX averaged less than $10 \%$ completion rates in 2016. ${ }^{91}$ In comparison, edX's 2016 completion rates were much higher for courses requiring a fee. ${ }^{92}$ This suggests that low completion rates can be attributed to the lack of financial investment from students, which allows them to drop the course without any adverse monetary consequences. ${ }^{93}$

\section{B. Blended/Hybrid Courses, Including Flipped Classrooms}

Blended, or hybrid, learning combines elements of the traditional face-to-face and online classrooms. ${ }^{94}$ It includes moving some, but not all, of the instruction to the online format and supplementing classroom instruction with online activities. ${ }^{95}$

The blended class structure can take many forms,${ }^{96}$ including the flipped classroom structure discussed more fully below. ${ }^{97}$ In some forms, the online component is used to replace some traditional face-to-face class time ${ }^{98}$ while in others, it may not replace much face-to-face class time at all. ${ }^{99}$ For example, a professor could decide to have one-third of the class online with the other two-thirds in the classroom, while another could decide to have face-to-face class meetings at the beginning and end of the semester with the rest of the class conducted online. ${ }^{100}$

Because hybrid courses can take many forms, the roles of the professor and students vary depending on what the professor decides to place online. The professor may only post a lecture online for a student to watch before the next face-to-face class session, ${ }^{101}$ or the professor might require students to complete an activity, such as take an online quiz, participate in

89. See MOOCS II, supra note 77.

90. MOOCS II, supra note 77 (noting that completion rates are "often less than $10 \%$ ").

91. Doug Lederman, Why MOOCs Didn't Work, in 3 Data Points, INSIDE HigHER ED (January 16, 2019), https://www.insidehighered.com/digital-learning/article/2019/01/16/study-offers-datashow-moocs-didnt-achieve-their-goals [https://perma.cc/MM7A-8N7S].

92. Id.

93. Id.

94. Huffman, supra note 14 , at 59 .

95. Jennifer Shea et al., Hybrid Course Design: Promoting Student Engagement and Success, 21 J. PuB. AfF. EduC. 539, 539 (2015).

96. See Huffman, supra note 14, at 58-59.

97. See infra notes $117-30$ and accompanying text.

98. Hess, supra note 26, at 56.

99. Hermann Kurthen \& Glenn G. Smith, Hybrid Online Face-to-Face Teaching: When Is It an Efficient Learning Tool?, 12 INT'L J. LEARNING 237, 237-38 (2005/2006).

100. Hess, supra note 26, at 57-58.

101. See infra text accompanying note 118 . 
a real-time online chat room, post on a discussion board, ${ }^{102}$ or respond to questions about the reading assignment. ${ }^{103}$

While some university officials "have reservations about the relative quality of online learning," they are most enthusiastic about blended/hybrid courses and "consistently rate the promise of blended . . . courses as superior to that of fully online courses." 104 Additionally, they "rate the learning outcomes for blended instruction as superior to traditional faceto-face instruction." ${ }^{105}$ These beliefs about blended/hybrid learning may have some support. According to a 2010 U.S. Department of Education meta-analysis of online education studies, ${ }^{106}$ there was "an average of 35 percent stronger learning outcomes for students taught in a blended format, as opposed to just face-to-face teaching." 107

Blended learning can be advantageous because online material can supplement in-class instruction, allowing professors to spend more class time addressing misunderstandings and having the students apply the material. ${ }^{108}$ For example, if the professor assigned a quiz for students to complete online prior to class, the professor could look at the results and tailor a short in-class lecture to reteach the misunderstood material. If the professor instead assigned the students a reading assignment and lecture outside of class, the students could bring their misunderstandings to the professor's attention in class. Blended learning also allows students to learn the content on their own schedule, revisit online material as much as they want, and control the pace at which they receive the information within the confines of due dates provided by the professor. ${ }^{109}$

Students participating in studies have commented that blended courses provide "opportunities for collaboration in online activities, increased opportunities for students to receive feedback, and a different way

102. Kurthen \& Smith, supra note 99, at 237.

103. Hess, supra note 26, at 58 .

104. I. Elaine Allen \& JefF Seaman with Russell Poulin \& Terri Taylor Straut, ONLINE REPORT CARD: TRACKING ONLINE EDUCATION IN THE UNITED STATES 31 (2016).

105. Id. at 32 .

106. Barbara Means et al., U.S. Dep'T of Educ., Evaluation of Evidence-Based PRACTICES IN ONLINE LEARNING: A META-ANALYSIS AND REVIEW OF ONLINE LEARNING STUDIES 19 (2009).

107. William R. Slomanson, Blended Learning: A Flipped Classroom Experiment, 64 J. LEGAL EDUC. 93, 95 (2014).

108. Hess, supra note 26, at 59.

109. See Landrum, supra note 14, at 270 ("The flexibility of video access allows students to 'choose exactly when they wish to learn.' Students can watch the videos repeatedly if they are having a hard time understanding concepts or wish to review material." (footnote omitted) (quoting Peter Sankoff, Taking the Instruction of Law Outside the Lecture Hall: How the Flipped Classroom Can Make Learning More Productive and Enjoyable (for Professors and Students), 51 ALBERTA L. REV. 891, 902 (2014)); Peter Sankoff \& Craig Forcese, The Flipped Law Classroom: Retooling the Classroom to Support Active Teaching and Learning, 2015 CAN. LEGAL EDUC. ANN. REV. 119, 130 (2015) ("[Students] listen ... on their own time outside of the class."); Vicki Simpson \& Elizabeth Richards, Flipping the Classroom to Teach Population Health: Increasing the Relevance, 15 NURSE EDUC. PRAC. 162, 165 (2015) ("The new course design allowed them greater flexibility and the ability to control the pace of learning."). 
for students to participate in class discussions." ${ }^{110}$ Furthermore, they note that they have better interactions with professors in blended courses than in pure classroom settings, citing the combination of "face-to-face communication in class, frequent email exchanges, and frequent postings to the course discussion board." ${ }^{111}$ Professors have noted that the format of blended courses (1) provides them with better access to students who have other obligations, like work and family; and (2) increases student engagement because students have time to reflect more deeply on what they have learned before responding on a discussion board or submitting an assignment. ${ }^{112}$

However, blended learning does have its drawbacks. Blended learning requires substantial work on the front-end for professors in terms of planning which classes will be presented online, developing lectures, and creating as well as coordinating assignments for the online and in-class components. ${ }^{113}$ Students have noted that blended courses can be problematic when there are technical difficulties on the course website, a professor is not quick to respond electronically to a student, or when fellow students working in a group fail to meet a deadline. ${ }^{114}$ Furthermore, because a blended course is not entirely online, students are still required to come to campus, removing some of the flexibility of fully online classes. ${ }^{115}$ Finally, some professors may simply "add online activities to an existing face-toface course" without decreasing the face-to-face classroom time, "resulting in an excessive workload that overwhelms students." 116

Flipped classrooms are a type of blended, or hybrid, teaching model where the professor literally flips the activities that students do in the classroom and at home: students receive instructional lectures online and complete activities in the classroom to apply their knowledge. ${ }^{117}$ The professor may require that the students complete a reading assignment and watch a prerecorded lecture online that explains the material more in-depth before the classroom meeting. ${ }^{118}$ Instead of being used for a lecture, class time is then spent on student engagement with active learning activities, such as in-class quizzes and group problem-solving activities. ${ }^{119}$ For example,

\footnotetext{
110. Hess, supra note 26, at 59.

111. Id. at 61 .

112. Id. at $62-63$

113. Id. at 64 .

114. Id. at 62

115. Bassou El Mansour \& Davison M. Mupinga, Students' Positive and Negative Experiences in Hybrid and Online Classes, 41 C. STUDENT J. 242, 247 (2007).

116. Hess, supra note 26, at 80.

117. Simpson \& Richards, supra note 109 , at 163.

118. Sankoff \& Forcese, supra note 109, at 132-33.

119. Id. at 121 .
} 
criminal law students could be required to provide a sentencing or charging recommendation. ${ }^{120}$

In the context of law schools, one professor observed that "[a]dopting a flipped classroom approach allows lawyering skills faculty to maximize the degree of in-depth instruction, the amount of practice students do under the instructor's guidance, and the number of opportunities for students to engage in learning activities in the classroom."121 Another professor remarked that the thoughtful infusion of online components into instruction can increase student engagement and enthusiasm both inside and outside the classroom, ${ }^{122}$ while yet another found the process of flipping a law classroom forces professors back into the shoes of students, allowing for more appropriate scaffolding. ${ }^{123}$

Despite these benefits, there are also some downsides to the flip. Faculty who flipped their classrooms found they spent more time on class preparation because of the need to generate and upload online content, as well as to coordinate it with in-class activities. ${ }^{124}$ Initial work included "identify[ing] the topic of each module, plan[ning] how the module integrates with what will happen during class, draft[ing] a script or develop[ing] other materials for the module, develop[ing] competency in using the technology needed to create the video, and creating and editing the video." 125 However, some faculty who have used the flipped classroom approach, such as Dr. Landrum, see the initial time commitment as a "onetime investment[]" because "[o]nce resources have been created, they can be used over and over again with little to no modification." 126 Others, though, may not see the benefits of the flipped classroom if students "do not put in the time required outside of class to be prepared for in-class activities." $" 127$

Some students find the flip helps them take more responsibility for their learning and increases their understanding because they have more access to the professor in the classroom, who is not using up all of the class time lecturing. Furthermore, students state that they are able to work with other students in groups during class time, and can rewatch video lectures

120. See Shawn Marie Boyne, Giving Students a Seat at the Table: Using Team-Based Learning in Criminal Law, 51 IND. L. REV. 440, 441, 444 (2018).

121. Matamoros, supra note 56, at 116-17.

122. Landrum, supra note 14 , at 259.

123. Sankoff \& Forcese, supra note 109, at 139.

124. Landrum, supra note 14, at 271; see also Simpson \& Richards, supra note 109, at 166 (commenting that professors may spend more time developing in-class activities using the flipped approach).

125. Landrum, supra note 14, at 271.

126. Id. at 277 .

127. Simpson \& Richards, supra note 109, at 166. 
to better enhance their knowledge. ${ }^{128}$ Other students, though, find the transition to a flipped classroom difficult due to the greater responsibility and workload outside of the classroom compared to the traditional class setting. ${ }^{129}$ For example, one law school professor at IU McKinney who used Team-Based Learning, a form of a flip, in a first-year class encountered some student resistance because it was the only first-year class not using the Socratic method and did not include PowerPoint slides like the other courses. ${ }^{130}$

In short, the evidence suggests that whether a blended or hybrid teaching model, including a flipped classroom, is successful depends significantly on the professor teaching the course. The strengths of this class format can be lost due to problems such as poor planning and organization by professors, and technical problems with the online component. ${ }^{131}$ For example, professors who have not taken the time to provide sufficient clarity on assignments leave their students feeling frustrated, ${ }^{132}$ whereas "[s]tudents who have a clear sense of what the course plan is will be more likely to actively and positively engage in learning activities." 133

\section{Non-MOOCs Fully Online Courses}

Outside of MOOCs, universities may choose to provide two other types of completely online courses: synchronous online courses and asynchronous online courses. Fully online and blended or hybrid online courses can be offered synchronously or asynchronously. ${ }^{134}$

\section{Synchronous Courses}

Synchronous online courses "occur on set schedules and time frames. Students and professors are online at the same time ... [and] lectures, discussions, and presentations take place at specific hours. All students must be online at that same exact time to participate in the class." 135 Professors can broadcast lectures and run all other aspects of the course through online platforms such as "Adobe Connect, Blackboard Collaborate, WebEx, and Saba Centra." 136 These platforms offer file sharing among users, electronic whiteboards that both professors and students can use and view,

128. Matamoros, supra note 56, at 125-26; see also Boyne, supra note 120, at 443 (expressing the view of a student who stated, "The [in-class] quizzes forced me to stay on top of the reading.").

129. Simpson \& Richards, supra note 109, at 165-66; see also Matamoros, supra note 56, at 126 (explaining that some students felt that the "course took up considerably more time than if it were taught in a traditional manner, possibly to the detriment of their performance in other courses").

130. See Boyne, supra note 120 , at 445 .

131. Shea et al., supra note 95, at 542; see also Kurthen \& Smith, supra note 99, at 242.

132. Hess, supra note 26, at 81.

133. Id. at 79 .

134. Synchronous vs Asynchronous Learning, ELEARNERS, https://www.elearners.com/education-resources/degrees-and-programs/synchronous-vs-asynchronous-classes/ [https://perma.cc/3H7FP7KF] (last visited Feb. 28, 2019).

135. Id.

136. Florence Martin \& Michele A. Parker, Use of Synchronous Virtual Classrooms: Why, Who, and How?, 10 J. ONLINE LEARNING \& TEACHING 192, 193 (2014). 
chat features that allow for conversations between groups or individual users, computer microphones that permit discussions between the professor and a student, webcams, and the ability to save sessions for later viewing. ${ }^{137}$ These features mimic those of a traditional course but "from anywhere, without having to physically travel to a traditional classroom."138

Given the features available in online platforms, the professor in a synchronous online course can deliver a live lecture and call on a student like in a traditional classroom, and the students can interact with the professor and each other through audio or chat features during the lecture. ${ }^{139}$ The professor can also assess students' through quizzes and written exams. ${ }^{140}$ Using an online platform, a professor can create an electronic quiz, proctor the quiz via webcams, and set an electronic due date. ${ }^{141}$ The professor can use a similar structure for the submission of written exams, creating an electronic exam and requiring students to use webcams so that they can be monitored through the testing periods. ${ }^{142}$ Students can respond to the exam questions using a word processor program on their own computer or a similar function in the online platform. ${ }^{143}$

The benefits of synchronous online courses include the ability of professors or students to participate in a course long-distance, and the opportunity for programs across multiple schools to jointly participate in a course. ${ }^{144}$ Given the online platform's tools promoting communication, these courses can "provid[e] immediate feedback" similar to a traditional classroom. Students may enjoy this environment more than an asynchronous course (discussed below) because of the "increased opportunity to interact with faculty and other students." 145 Students can also pose questions to the professor during a lecture using a chat feature instead of the

\footnotetext{
137. Id.

138. Id.

139. Synchronous vs Asynchronous Learning, supra note 134.

140. Nian-Shing Chen et al., Design and Implementation of Synchronous Cyber Assessment and Its Potential Issues, in PROCEEDINGS OF THE 17TH INTERNATIONAL CONFERENCE ON COMPUTERS IN EDUCATION [CDROM] 905, 906 (Kong, S.C. et al. eds., 2009).

141. Id.

142. Id.

143. Id.

144. See, e.g., Ellen S. Podgor, Teaching a Live Synchronous Distance Learning Course: A Student Focused Approach, 2006 U. ILL. J.L. TECH. \& POL'Y 263, 263 (2006) (detailing the author's experience teaching a synchronous international criminal law course through Georgia State University College of Law, with Georgia State law students participating along with Brandeis School of Law students in Louisville, Kentucky).

145. Devon Haynie, Decide Between Live, Self-Paced Online Classes, U.S. News \& WoRLD REP. (Jan. 5, 2015, 9:30 AM), https://www.usnews.com/education/online-education/articles/2015/01/09/decide-between-live-self-paced-online-classes (noting that synchronous classes allow a student to "feel like being in a regular classroom"); Martin \& Parker, supra note 136; see also Synchronous vs Asynchronous Learning, supra note 134 (noting that students want to "feel involved, in real-time, with the class experience. They might find it rewarding to ask a question or offer a comment, and to receive instant feedback.").
} 
microphone, allowing the professor to remain uninterrupted while everyone can see the question. ${ }^{146}$ Finally, saved recorded sessions of a synchronous online class allow students to later review and enhance their understanding of the material. ${ }^{147}$

However, these courses also present challenges for the professor, including the unlimited accessibility provided by online platform features. For example, the chat feature enables students to submit potentially unlimited questions during a lecture, requiring the professor to multitask between delivering instruction and monitoring a growing chat feed. ${ }^{148}$ Furthermore, the use of a webcam does not allow the professor to simply point to call on a student, which requires a shift from a traditional classroom practice. There may be so many students participating in the course it could be difficult to see and track all of the students on the professor's screen. ${ }^{149}$ There is also the possibility of technical issues for both the professor and the students, so a professor should consider the type of institution or online platform support available to address those issues should they arise. ${ }^{150}$ Finally, the "work involved in teaching this type of class [can be] significantly greater than when teaching a live class."151

For the student, a major disadvantage is that synchronous online courses provide less flexibility for those with family or work obligations because there is a set schedule of when and how long lectures and other required log-in times will last. ${ }^{152}$ Yet, flexibility is what many students seek from an online course. ${ }^{153}$

\section{Asynchronous Courses}

Technological developments now allow schools to offer fully online asynchronous courses. ${ }^{154}$ The ABA has approved them, but has required that such courses include interaction that is similar in kind and quality to

\footnotetext{
146. Martin \& Parker, supra note 136, at 194.

147. Id. at 202 .

148. Id. at 194

149. Podgor, supra note 144, at 270.

150. Id. at $267-68$.

151. See id. at 271 (describing her experience of teaching a synchronous course to her home institution in Georgia and to another institution in Kentucky, and noting that she would do it again with modifications, such as having better technical assistance available and limiting student enrollment so that she could more easily see all students on her screen).

152. Synchronous vs Asynchronous Learning, supra note 134.

153. Hammond et al., supra note 86 , at 528.

154. Harasim, supra note 25 , at 44-45 (describing the technological advances beginning in the 1970s that make online education in general possible, including educational use of computer networking beginning in the 1970s, the first online courses and the increased access to computers and networks in the 1980s, and the rise of national educational networking programs in the 1990s).
} 
that offered in live law classes. ${ }^{155}$ Asynchronous courses are the subject of our study. ${ }^{156}$

Asynchronous online courses are "time-shifted" and consist of "readings, recorded lectures, and student activities posted for students to access." ${ }^{" 157}$ In these courses, the students and professor do not meet in real time-online or otherwise. ${ }^{158}$ Rather, in an asychronous class, teaching and learning is conducted through an online platform (at IU McKinney, it is "Canvas"), with lessons organized by "modules" containing recorded lectures by the professor, readings, supplemental videos (such as portions of a documentary or videos from institutions like the United Nations), and student activities. ${ }^{159}$ The professor assesses student learning through regular student activities, which may consist of quizzes, discussion board posts, research assignments, or short papers. ${ }^{160}$ The professor then provides feedback on those assignments through communication tools available on the online platform. While students must submit activities by a specific date, they can choose the exact day or time within the week to watch lectures, complete readings, and work on activites without attending a live classroom session. ${ }^{161}$

Asynchronous courses are desirable because they provide flexibility to evening students with daytime commitments and to all students with packed schedules. ${ }^{162}$ As Professor Max Huffman explains, asynchronous courses allow students increased flexibility to, for example, finish their final semester in law school while also pursuing an externship in Brussels or Washington, D.C.- putting them at a competitive advantage in the

155. STANDARDS \& RULES OF PROCEDURE FOR APPROVAL OF LAW SCHOOLS Standard 306 (AM. BAR ASS'N 2017-2018), https://www.americanbar.org/content/dam/aba/publications/misc/legal_education/Standards/2017-2018ABAStandardsforApprovalofLawSchools/2017_2018_aba_standards rules approval law schools final.authcheckdam.pdf [https://perma.cc/9G3 $\overline{\mathrm{V}}-7 \mathrm{FFF}]$.

156. See infra Part III.

157. Huffman, supra note 14 , at 58-59.

158. See Haynie, supra note 145 (stating that asynchronous courses let students "sign on and view course readings or videos when they please"); Synchronous vs Asynchronous Learning, supra note 134 (describing asynchronous courses as allowing students to "complete their work on their own time").

159. See Synchronous vs Asynchronous Learning, supra note 134 (explaining the supplemental digital materials in asynchronous courses, such as PowerPoints, documents, podcasts, and videos).

160. Huffman, supra note 14, at 77 (using "quizzes, writing assignments, [and] discussion boards" in his asynchronous online Comparative and International Competition Law course); Swift, supra note 14, at 112 (explaining various assignments assigned in his asynchronous Employment Law and Transactional Drafting courses, such as questions about the reading, short answer questions to apply knowledge, group discussion questions, researching applicable law, and drafting assignments).

161. Haynie, supra note 145 (stating that these courses allow students to "sign on and view course readings or videos when they please, meeting deadlines while studying at their own pace"); Synchronous vs Asynchronous Learning, supra note 134 (explaining that "[s]tudents are given a timeframe - it's usually a one-week window - during which they need to connect to their class at least once or twice").

162. Cahak, supra note 27, at 527-28 (arguing that online distance courses make law school accessible to older students with family and work responsibilities); Haynie, supra note 145 ("Many online students are juggling work and family commitments, and they don't always have time to log in at a certain hour."); Synchronous vs Asynchronous Learning, supra note 134 (stating that asynchronous courses allow class schedules to "bend to accommodate your real life"). 
employment market. ${ }^{163}$ Asynchronous courses can also benefit students who are more comfortable writing than speaking because they have extended time to think before responding. ${ }^{164}$ Regular online assignments allow students multiple points of feedback, a rarity in law school where a student often only receives feedback from a final exam. ${ }^{165}$ Fully online asynchronous programs can also lower the costs of law school and permit more graduating students to pursue lower paying jobs in government or public service. ${ }^{166}$ Finally, the flexibility of asynchronous courses allows law schools to diversify their student bodies and recruit nontraditional students, such as adult learners with careers and families, ${ }^{167}$ students with disabilities, ${ }^{168}$ and students from low socioeconomic backgrounds. ${ }^{169}$

However, not all professors and students are sold on the concept of asynchronous course delivery in the law school context. Some students miss the live interaction and engagement of traditional or synchronous classes. ${ }^{170}$ Others in the legal field are dissatisfied with the fact that asynchronous courses do not allow professors to teach using the Socratic method, which proponents consider an effective active learning teaching methodology. ${ }^{171}$ Critics of asynchronous courses also argue that the law school market is already saturated, and that fully online law schools are run by for-profit institutions seeking money instead of attempting to provide students with an education. ${ }^{172}$ Finally, an asynchronous course may not match everyone's learning style. ${ }^{173}$

Critics are right that the professor will not be able to use the Socratic method in an asynchronous class. However, employing the Socratic method is only one active-learning method that a professor can use to engage students and encourage learning. There are many reasons to believe

163. Huffman, supra note 14, at 67.

164. Haynie, supra note 145; Swift, supra note 14, at 136 (observing more extensive responses in his asynchronous online course, likely because "students in the online format have the opportunity to really digest what the other students have written and then spend ten to fifteen minutes responding to the posts").

165. Swift, supra note 14 , at $141-43,145-47$.

166. Bennett, supra note 1, at 5-6.

167. Swift, supra note 14, at 157-58 (explaining that asynchronous courses allow nontraditional students to attend courses less frequently during the week and control when they will engage with the material).

168. Id. at 158-60 (noting that online platforms could allow students with attention deficit disorder to break up a lecture into chunks, and closed captioning could benefit students who speak English as a second language).

169. Cahak, supra note 27, at 521-22.

170. Haynie, supra note 145.

171. Huffman, supra note 14, at 61 (explaining that some law professors reject the online experience because they believe it "undermines the [in-person] Socratic dialogue"); see also Swift, supra note 14, at 116-17 (noting that detractors of the Socratic method believe it provides an active learning experience only for the student being questioned and a passive learning experience for the rest of the students listening).

172. Cahak, supra note 27, at 520-23.

173. Mansour \& Mupinga, supra note 115, at 246-47. 
that a professor or law school can use developing technology to deliver quality teaching and learning asynchronously in law school courses. ${ }^{174}$

Studies show that the professor plays a large role in whether an online course delivers quality instruction to the student. In fact, a 2005 U.S. Department of Education meta-analysis of online education studies found professor involvement in online courses to be the determinative factor in whether the online course was just as effective, if not more so, than the traditional face-to-face setting. ${ }^{175}$ It found that " $[\mathrm{w}]$ hen instructor involvement was ranked as low, such as courses where students interact with the computer alone, face-to-face instruction was significantly more effective than distance instruction. Conversely, when instructor involvement was rated as medium or high, distance education was significantly more effective." 176 These findings should not be surprising because a successful live classroom experience also depends on a professor's level of preparation for class and ability to manage the classroom environment in a way that encourages student learning and interest.

\section{RESEARCH DESIGN: THE IU MCKINNEY STUDY ASSESSING ASYNCHRONOUS ONLINE PROGRAMMING}

To assess the effectiveness of asynchronous online classes, this study draws on evidence from (1) anonymous student survey responses; and (2) focus groups with students. In both cases, the students responding were currently enrolled law students at IU McKinney.

\section{A. Anonymous Student Surveys}

In terms of the survey responses, we collected data over a two-year period from more than 300 students in different sections of two different fully asynchronous online classes: Online Trusts and Estates and Online Comparative Law. ${ }^{177}$ A total of 283 of 316 students responded to the survey in Online Trusts and Estates during the Spring 2015, Spring 2016, and Fall 2016 semesters. A total of 43 of 64 students responded to surveys administered in Online Comparative Law during the Spring and Fall 2016 semesters. Professor Ryznar taught all of the Online Trusts and Estates classes, and Professor Dutton taught all of the Online Comparative Law classes. Both classes were organized into modules and included short rec-

174. See supra notes 56-173 and accompanying text; infra Part IV.

175. Hess, supra note 26, at 82 .

176. Id.; see also Kurthen \& Smith, supra note 99, at 239 ("How much and how quickly the instructor responds is a major factor in student satisfaction.").

177. Survey by Yvonne Dutton, Professor of Law, Ind. Univ. Robert H. McKinney Sch. of Law (Spring 2016) (on file with authors); Survey by Margaret Ryznar, Professor of Law, Ind. Univ. Robert H. McKinney Sch. of Law (Spring 2015) (on file with authors); Survey by Margaret Ryznar, Professor of Law, Ind. Univ. Robert H. McKinney Sch. of Law [hereinafter Fall 2016 Dutton Survey] (Fall 2016) (on file with authors); Survey by Margaret Ryznar, Professor of Law, Ind. Univ. Robert H. McKinney Sch. of Law (Spring 2016) (on file with authors). The 85\% response rate results from combining all responsive students regardless of the course. 
orded lectures by the professor and various activities to assess student understanding of the material. Some of those activities were similar-for example, both Professors Dutton and Ryznar required students to complete quizzes. ${ }^{178}$ Some assignments, however, were only appropriate for certain types of classes. For example, in Professor Dutton's course, students were required to write comparative analysis memos.

The surveys to which students responded were "unofficial" mid-semester surveys that were administered in an effort to receive anonymous feedback from students about the class in time for the professor to adjust the delivery and content if necessary. In contrast, the end-of-semester official surveys were administered too late to allow such adjustments in response to student feedback. Students were not required to fill out these mid-semester surveys; however, $85 \%$ of students did. ${ }^{179}$

The surveys included a number of questions seeking student input about what was or was not working in the class generally. One question was specifically designed to learn the students' overall impression of their online experience-it asked students: Would you take another "online" class in the future? Why or why not? This Article presents the data from student responses to that question below, exploring not only data on the percentage of students who responded positively or negatively to that question, but also why students reached their conclusions.

The data received in response to this survey question reflects the perception of IU McKinney students about online courses more generally for several reasons. First, more than 300 students responded to the survey questions about their online course experience. Second, the data was collected over several different semesters, allowing for examination of student perception over a period of time. Third, this study includes variation across courses and professors, allowing some conclusions about whether certain findings persist across that variation. For example, this study includes two different types of courses taught by different professors-

178. Quizzes are but one type of structured interim assessment that professors can use in their online courses. Quizzes can include various types of questions, such as multiple choice, true/false, fillin-the blank, and even short essay. See, e.g., Margaret Ryznar, Assessing Law Students, 51 IND. L. REV. 447, 450 (2018) ("The online learning platform is often able to grade objective quizzes such as multiple choice, and can even offer students immediate feedback by revealing the correct answers and explanations upon a student's submission of the quiz. The professor, meanwhile, receives a computergenerated report on student performance on that quiz once it closes," allowing the professor to monitor students' efforts at mastering course material).

179. See supra note 177. 
Trusts and Estates is a "black letter law"180 course, while Comparative Law is a seminar-style course. ${ }^{181}$

\section{B. Focus Groups}

To supplement and add depth to the data obtained from the anonymous surveys, this Article also includes data from focus group sessions designed to learn more about student perceptions of IU McKinney's online programming that consists of online courses beyond Trusts and Estates and Comparative Law. The data reveals what online learning methods students believe do and do not facilitate engagement and learning, and how they compare their online experiences to their live classroom experiences at the law school. ${ }^{182}$ In the focus group sessions, students were encouraged to interact with each other and discuss their experiences in online classes, with the goal being a much richer and detailed narrative than could obtain through the mid-semester surveys. ${ }^{183}$

This study targeted for participation graduating students who had taken at least one asynchronous online course at IU McKinney because graduating students likely would be most willing to speak freely during the focus group sessions about their experiences in online classes. This group had little reason to be concerned about negative repercussions to their responses because their remaining exams would be graded anonymously and they were only a month from graduation. ${ }^{184}$

Beyond targeting only graduating students, this study incorporated other measures to encourage students to speak frankly during the focus group sessions. First, students were told that while Professors Dutton and Ryznar were conducting the study, neither would be privy to the identity of students participating in the focus groups. Students were recruited for the focus groups by graduating student and author, Kayleigh Long. The focus groups were facilitated by Douglas Jerolimov from Indiana Univer-

180. "Basic standard rules that are generally known and free from doubt. The black letter law on any subject consists of rules that can be applied in a very mechanical way without moral qualms or other considerations." Black Letter Law, CORNELL L. SCH.: WEX, https://www.law.cornell.edu/wex/black_letter_law [https://perma.cc/A9YR-UUQV] (last visited Feb. 28, 2019).

181. "A class at university in which a topic is discussed by a teacher and a small group of students.” Seminar, OXFORD LIVING DICTIONARY, https://en.oxforddictionaries.com/definition/seminar [https://perma.cc/ZAK9-4PUE] (last visited Feb. 28, 2019).

182. Focus groups consist of groups of individuals who are assembled to discuss, based on their personal experience, the topic that is the subject of the research. Dominic Sagoe, Precincts and Prospects in the Use of Focus Groups in Social and Behavioral Science Research, 17 QUALITATIVE REP., Article 29, at 1 (2012).

183. See, e.g., Ivana Acocella, The Focus Groups in Social Research: Advantages and Disadvantages, 46 QUALITY \& QUANTITY 1125, 1129 (2012) (noting that focus group researchers encourage participants to talk, debate, and interact with one another).

184. For most courses at the IU McKinney School of Law and other law schools, much or all of the grading is done anonymously, with professors only receiving exams with randomly assigned student identification numbers, rather than student names. Names are only revealed to professors after the grades have been given to the administration. 
sity-Purdue University Indianapolis's Center for Teaching and Learning. ${ }^{185}$ Dr. Jerolimov scrubbed the transcripts of the focus groups of any identifying student information before providing those transcripts to Professors Dutton and Ryznar. In addition, Dr. Jerolimov, who is trained and experienced in facilitating focus groups, advised students that they should keep confidential the identity of focus group participants and the information shared by those participants. Finally, Dr. Jerolimov told focus group participants that, to the extent they had any concerns about confidentiality, they need not mention professors or courses by name when commenting during the sessions. Students were free to avoid answering any particular question or to leave the focus group entirely at any time.

We held three different focus groups in April 2018, with four to eight students in each. The first was on April 11 at 3:00 p.m. (Focus Group 1) with six students, the second was on April 12 at 12:45 p.m. (Focus Group 2) with eight students, and the third was on April 12 at 4:30 p.m. (Focus Group 3) with four students. Each session took place in a conference room at the law school and lasted between one and one and a half hours. Dr. Jerolimov videotaped each session, and the sessions were transcribed by an outside service. ${ }^{186}$ Students were offered no incentive to participate in the study, other than the opportunity to share their views about the current online programming and any suggestions for improvement. To help students save time and to recognize their contribution to the project, each student participant was offered a sandwich and beverage during the sessions.

During the focus group sessions, Dr. Jerolimov used a script containing suggested questions designed to learn more about student perceptions of online classes at IU McKinney. Those questions specifically asked students to compare their experiences in online classes with their experiences in live classes. For example, one question stated: "How do you compare the online experience to the live experience in terms of student engagement-being engaged in learning the course material?" Another asked: "How do you compare the online experience to the live experience in terms of student learning - actually learning the course material? Do you feel students learn more or less in one environment or the other? Be specific about what learning was (or was not) improved, and why you think it was (or was not) improved." 187

Additional questions were similarly focused on assessing the quality of online teaching and learning. Students were asked, among other things, what kinds of students they thought benefited most from online courses;

185. Douglas Jerolimov, $\mathrm{PhD}$, is an instructional consultant at the Center for Teaching and Learning at Indiana University-Purdue University Indianapolis (IUPUI). He has conducted numerous focus group discussions for program evaluation and development efforts, as well as student focus groups for mid-term course evaluations. Dr. Jerolimov also serves as an IUPUI Campus Coordinator for the Quality Matters organization, a quality assurance organization for online teaching and learning.

186. The outside transcription service was Rev, available at https://www.rev.com.

187. See infra Appendix A. 
whether they believed students would benefit from more online programming; and what advice they would offer to improve the school's online programming. A copy of the entire script Dr. Jerolimov used for the focus groups is attached as Appendix A.

The next Part presents and discusses the data obtained from the anonymous surveys and focus groups as it relates to: (1) student interest in asynchronous online programming; and (2) student evaluations of online programming, especially as compared to live classroom courses.

\section{STUDY RESULTS AND DISCUSSION}

The extant studies assessing student perceptions of online courses do not point unequivocally to a conclusion that students view both online and live courses as delivering the same quality learning experience. ${ }^{188}$ Some studies on online instruction in the undergraduate and graduate contexts show students performing better in or preferring the online format. ${ }^{189}$ Other studies show students performing better in or preferring the traditional classroom. ${ }^{190}$ For example, in one article, the authors report that undergraduate student surveys conducted during 2012 and 2013 showed that

188. As one author puts it, "Most of the studies have mixed results: on some of the measures, the students in the online or hybrid format did better, but on others they did worse, relative to students in the face-to-face format - or else, on some measures the online- or hybrid-format students did significantly better or worse than the students in the face-to-face format, but on other measures there was no significant difference between the two groups.” KELLY A. LACK, CURRENT STATUS OF RESEARCH ON ONLINE LEARNING IN POSTSECONDARY EDUCATION 11 (2013).

189. See, e.g., Durant Frantzen, Is Technology a One-Size-Fits-All Solution to Improving Student Performance? A Comparison of Online, Hybrid and Face-to-Face Courses, 20 J. PUB. AFF. EDUC. $565,565,574$ (2014) (examining student performance in online, hybrid, and face-to-face courses in an undergraduate criminology program and finding that student performance significantly improved in the online course compared to the hybrid and face-to-face courses); Porter et al., supra note 56, at 8 (examining student performance and perceptions in an online and face-to-face undergraduate immunization course and finding no difference in student performance, but noting that " $\mathrm{t}] \mathrm{hree}$ times as many students in the online section preferred an online delivery method at the end of the semester compared to the beginning, whereas fewer students in the classroom section preferred taking a classroom course"); Linda Wiechowski \& Terri L. Washburn, Online Finance and Economics Courses: A Comparative Study of Course Satisfaction and Outcomes Across Learning Models, 7 AM. J. BUS. EDUC. 37, 41, 45 (2014) (examining student performance and perceptions in online, blended, and face-toface undergraduate and graduate finance and economics courses and finding that "[s]tudents taking online and blended courses were more satisfied with their courses than were those who opted for the face-to-face learning model" but finding no difference in student outcomes).

190. See, e.g., Kelly Bergstrand \& Scott V. Savage, The Chalkboard Versus the Avatar: Comparing the Effectiveness of Online and In-Class Courses, 41 TEACHING Soc. 294, 294, 302 (2013) (examining student perceptions of online and face-to-face undergraduate sociology classes and finding that "[o]nline courses receive lower overall course ratings, and students state that they learn less in online courses"); D. Kevin O'Neill \& Tzy Horng Sai, Why Not? Examining College Students' Reasons for Avoiding an Online Course, 68 HIGHER EDUC. 1, 4, 10 (2014) (examining undergraduate online and face-to-face educational psychology courses and find that "students' beliefs about the best conditions to support their learning appeared to play a large role in their decision. They proved willing to invest quite a bit of time and endure substantial inconvenience in order to secure those conditions."); Jeremy I. Tutty \& James D. Klein, Computer-Mediated Instruction: A Comparison of Online and Face-to-Face Collaboration, 56 EDUC. TECH. RES. \& DEV. 101, 105, 118, 120 (2008) (examining collaborative learning in undergraduate online and face-to-face computer literacy courses and finding that students in the face-to-face course "performed significantly better on the individual posttest than those in the virtual online condition" and that "students in the virtual condition were significantly less 
the majority of students prefer live classes to online classes. ${ }^{191}$ Those authors further reported that $32 \%$ of students in 2013, and $43 \%$ in 2012, felt that they learned less in online classes than in live classes. ${ }^{192}$ The authors' conclusion, based on their survey results, is that "if given a choice [students] would prefer the traditional classroom experience." 193

That these studies do not unequivocally demonstrate the benefits of online teaching and learning, however, does not mean that we should dismiss online classes. As mentioned above, we do not expect that every student will feel comfortable in the online environment. Also, some of the studies were conducted several years ago. ${ }^{194}$ Online classes are improving over time with technological developments that make the online learning platform more robust and user-friendly. ${ }^{195}$ Professors are also learning how to make their courses more engaging for students from their own trial and error - and from reading the pedagogical literature on online teaching. ${ }^{196}$

In short, we urge an open mind as to the future of online teaching and learning in the law school environment. Our own data suggests that online classes have a place in the law school curriculum, as the vast majority of students would take another asynchronous online class. Students also generally expressed the view that at least some of the online classes they have taken deliver a learning experience that is equal to or better than the learning experience they had in some traditional live law classes.

Why do the students express this view? After reviewing the data, we conclude that quality matters in online teaching, just as it does in live teaching. In particular, the data shows that there are several key components to the learning experience that will make students appreciate their online course. If professors design and deliver their online courses taking these factors into account, this Article predicts that students will perceive the courses as delivering a learning experience similar to the quality live courses they have taken.

\footnotetext{
positive than students in the face-to-face condition toward the delivery system, the topic, and collaborative work").

191. Holly J. Seirup et al., Online Education: Panacea or Plateau, J. FOR LEADERSHIP \& INSTRUCTION, Spring 2016, at 5,7.

192. Id. at 6.

193. Id. at 8; see also Bergstrand \& Savage, supra note 190, at 302 (noting a negative perception of online sociology courses among undergraduate students); O'Neill \& Sai, supra note 190, at 10 (finding undergraduate students self-selecting into a face-to-face course instead of taking the same course online because of "the greater risk of failure or dropout associated with an online course").

194. See supra note 190 and accompanying text.

195. Michele Pistone, Law Schools and Technology: Where We Are and Where We Are Heading, 64 J. LEGAL EDUC. 586, 596 (2015).

196. Id. at 601-02.
} 


\section{A. Anonymous Survey Results}

The vast majority of students responding to the anonymous surveys indicated that they would take another asynchronous online class. For Professor Dutton's Online Comparative Law classes, of the forty-one students who responded to the question about taking another online class, $85 \%$ answered that they would. Arguably, this percentage does not fully capture students' preference for online programming because some students were coded as nonresponsive to the question because they answered, in effect, "No, because I am graduating." To the extent that students elaborated on their reasons for wanting to take another online class, they referenced the flexibility that the online course offered to them by allowing them to work, care for their family, and save time commuting while still learning and completing course work whenever and wherever they wanted.

Of the 278 students responding to this same question in Professor Ryznar's Online Trusts and Estates course, 74\% said they would take another online course. As with Professor Dutton's class, this percentage does not fully capture students' preference for online programming because some students simply responded, "No, because I am graduating," and other students had more equivocal responses that they would take another online course depending on the type of course, the professor teaching the course, and the structure or layout of the online course. Responses indicated that students wanted to take more online courses so that they could learn at their own pace, access resources that they may not have in a traditional face-to-face class, have flexibility in scheduling (especially helpful for evening students and those with families), and forgo commuting to campus.

That the vast majority of our respondents would take another online class should be encouraging to law schools considering investing in online programming. One can also conclude from the data that students responding to these survey questions believed that they had participated in a quality teaching and learning experience. Students did reference flexibility as a reason that they would be persuaded to take another online course, but they also mentioned that they would take another course depending on the professor teaching the course, the course's organization, and the type of course being offered online. We also expect that law school students would not take a class simply because it allowed them some flexibility in their schedule. In fact, at least nineteen students, across both courses, volunteered that they felt they learned just as much, if not more, than what they would have learned in a traditional classroom - and students were not asked this question in the anonymous survey.

It is no surprise that students would identify the flexibility of online programming as important in their decision to take a class online. The literature on online programming highlights flexibility as a key advantage to 
asynchronous online classes. ${ }^{197}$ Nor should one be surprised that law students who work full-time or have families would appreciate the ability to complete lectures and activities when they can. ${ }^{198}$

\section{B. Focus Group Results}

The focus group results are consistent with, and further elaborate upon, the mid-semester survey data. Students like the IU McKinney online programming, which goes beyond Online Trusts and Estates and Online Comparative Law, and would like more of it. This Section presents the focus group responses by theme and analyzes them accordingly.

\section{Student Engagement and Learning: Online Versus Live}

As to student engagement and learning, the most common student comment was that online and live classes both could offer more or less student engagement and learning depending on the topic being taught, the type of course, and the professor. ${ }^{199}$ In other words, students did not suggest that online courses on the whole offered any less of an opportunity for student engagement and learning than did live classes. Several comments help illustrate this point. One student stated: "I thought there was a lot of engagement in certain classes, and then in other classes there weren't. Same thing with online." ${ }^{200}$ The same student said that he or she has gotten a lot out of both in-person and live classes. ${ }^{201}$ Another student commented: "The more a teacher pulls me into it, the better. Some professors just haven't done that. Same with the live courses as well."202

Many students highlighted the importance of quality teaching in their comments about online teaching and learning. For example, one student stated that " $[t]$ he professor really is the key to any class, an in-person or an online. The professor's knowledge of whatever the subject material is and the professor's pedagogical style is really important." ${ }^{203}$ Another also said that the professor teaching the online course played a large role in

197. See, e.g., Bennett, supra note 1 (examining the flexibility of asynchronous online courses).

198. Joseph A. Rosenberg, Confronting Clichés in Online Instruction: Using a Hybrid Model to Teach Lawyering Skills, 12 SMU SCI. \& TECH. L. REV. 19, 44-45 (2008) (explaining that "[s]chedules are a key factor in how students perceive and experience the value and convenience of online activities”); Marilyn Odendahl, ABA Proposal Would Allow Law Schools to Offer More Classes Online, THEINDIANALAWYER.COM (Apr. 4, 2018), https://www.theindianalawyer.com/articles/46586-abaproposal-would-allow-law-schools-to-offer-more-classes-online [https://perma.cc/BQ5W-N9R2] (referencing an IU McKinney evening law student's impromptu poll that found many of her classmates saw online courses as appealing and wanted more of them).

199. As one student put it, the amount of work in the class and the level of engagement "just depends on what the class is, who the professor is, and how the class is taught." Yvonne M. Dutton \& Margaret Ryznar, Focus Group 3, at 6-7 (Apr. 12, 2018, 4:30 PM) [hereinafter Focus Group 3] (unpublished transcript) (on file with authors) (Student 1).

200. Yvonne M. Dutton \& Margaret Ryznar, Focus Group 1, at 2 (Apr. 11, 2018, 3:00 PM)

[hereinafter Focus Group 1] (unpublished transcript) (on file with authors) (Student 5).

201. Id.

202. Id. at 3 (Student 1$)$.

203. Id. at 24 (Student 4). 
whether the student viewed the course as a good learning experience. ${ }^{204}$ This focus on the professor's role is one that has also been highlighted in the literature. ${ }^{205}$ While Bergstrand and Savage found students preferred a traditional face-to-face sociology course over the same online course, they also found that,

[T] he effectiveness of online courses depends on the instructor teaching the course. It makes sense that the amount of time and energy put into an online course by an instructor ... will impact the effectiveness of Web-delivered courses. Our research also suggests that the skill sets and traits of instructors could make some individuals better suited to teach online courses. ${ }^{206}$

As to the relevant traits that may make a professor more successful, the authors mentioned the professor's general public speaking abilities and specific ability to engage students. ${ }^{207}$

Students in our focus groups also noted that the student plays a role in ensuring that the online environment is one in which he or she learns course material. In short, as long as the student is willing to do the work required by the professor, he or she can be engaged and learning in the online environment. ${ }^{208}$ One student noted that if the student did all of the work in the online class as required, "you're getting either equal or greater amount of information versus if you were in an in-class setting." ${ }^{209}$ Another student said,

It would be hard for me not to recommend an online course to anyone because I feel like I've learned so much in the online courses. Again, it goes to the type of student that you are. If you're somebody that you're going to schedule out the time, you're going to do the work, you're going to make the effort, then ... I've gotten out of each of my classes, I feel like, what I've put in. ${ }^{210}$

A different student pointed out that if he or she was "doing all the reading and doing all the work assigned and showing up to all the classes

204. See, e.g., Yvonne M. Dutton \& Margaret Ryznar, Focus Group 2, at 13 (Apr. 12, 2018, 12:45 PM) [hereinafter Focus Group 2] (unpublished transcript) (on file with authors) (Student 1: "It just all goes back to who is teaching the course, and how they structure it online.").

205. Bergstrand \& Savage, supra note 190, at 303.

206. Id.

207. Id.

208. Some students did note that different online courses had different levels of work required of them. By way of example, one student said that in a one-credit online course, he or she had more weekly assignments than he or she had in a three-credit online course. Focus Group 3, supra note 199, at 6 (Student 4). Another student said that he or she has been in online courses that were extremely difficult in terms of rigor and the amount of work required of the student, and some that required very little additional work from the student. $I d$. at 9 (Student 1). While we can consider ways to even out the amount of "rigor" in online classes, it is worth noting that live classes are not all the same in terms of rigor either. Students, in fact, made this point. See, e.g., id. (Student 3: "Just like all live classes are not the same, not every online class is the same either.").

209. Focus Group 1, supra note 200, at 14 (Student 3).

210. Id. at 16 (Student 5). 
or watching all the videos that are available, I'm learning. If I'm not, I'm not learning." "211 On the other hand, a couple of students noted that they could get away with doing less in an online environment than in a live environment because they did not have the possibility of being called on by the professor. ${ }^{212}$

A number of students, in fact, highlighted some benefits to the online course format as it relates to engagement and learning, and as it compares to live classroom learning. One student stated,

For me, what I have enjoyed about online classes is that most of them have some sort of application portion for each lesson. I learn well from that, as opposed to reading, Socratic method, and then putting it all together whenever you have a minute to outline. The online classes for me I think have been more conducive to my learning. ${ }^{213}$

Another similarly commented that the online classes tended to offer more "activities where you could actually apply what you're reading or learning [to what] the lecture is on [which] really helps you learn." 214 Another pointed out that in contrast to live classes where "if you know you're not going to be on call, [you can] go to class unprepared [and] sit back," with an "online class, I think every time you do something with the class, you're engaged." 115 One student suggested that he or she found little value in live classroom learning, stating that in live classes, "you show up for class, $10 \%$ of your grade is if you happen to be paying attention the day that you get called on, and then the rest is based off your final exam, but that's it." 216

Although many students highlighted how online classes offered them the opportunity to engage with the material because they had to complete regular assessments, some students did note that an aspect of live classes that they missed was the spontaneous interaction with the students and the professor-interaction that could contribute to learning. Along these lines, one student stated, "I think there is value to having the classroom experience, not only of having the professor be able to lecture to you on his or

211. Id. at 4 (Student 2). Other students made similar comments about the student's role in ensuring he or she was engaged and learning. See, e.g., Focus Group 2, supra note 204, at 6 (Student 6: "I really just think it depends, and I don't think my learning has been adversely affected by taking online classes versus in-person ones or vice versa. I think I just view the same thing regardless."); Focus Group 3, supra note 199, at 3 (Student 4: "I think engagement depends on kind of with what effort you put into it and also the structure of the course itself.").

212. See, e.g., Focus Group 3, supra note 199, at 2 (Student 1, stating that he or she could put the lectures on a fast speed to watch them and could even answer some discussion questions and quiz questions without doing the reading); id. at 2 (Student 2: "Engaged in the process of doing posts and quizzes and things like that, but as for actual engagement in learning the material, like getting coldcalled in class or having to defend your position, kind of less engaged.").

213. Focus Group 1, supra note 200 (Student 2).

214. Id. at 4 (Student 1).

215. Id. at 3 (Student 6).

216. Focus Group 2, supra note 204, at 5 (Student 7). 
her expertise but also in being required to engage with other students in that setting." ${ }^{217}$ Another noted,

The couple of online classes I've taken, I've watched the lectures, I've done the readings, but for me, it's not the same as when I can go and ask professors questions in an in-person setting. An online class, I might've done the reading about a particular case or statute, and then the professor will lecture over video. I don't have the opportunity during that video, when the professor is taking time to explain it, to actually ask more overarching or more nuanced questions. ${ }^{218}$

Another said that he or she really felt more comfortable in the live setting, noting that,

[E]ven if a professor's lecturing, and not asking questions, I'm still kind of in a sense thinking questions I could be asking or asking questions myself. And I guess that process for me is how I learn, so even though online I can maybe email a question, ${ }^{219}$ it just feels like, just because I guess the device is there that it's cut off, and it kind of throws me out of what I'm used to in terms of the Socratic kind of education and learning process it is that I kind of picked up through my schooling. ${ }^{220}$

One student suggested that certain kinds of classes might be better in a traditional classroom because they require more in-person discussion to facilitate learning. ${ }^{221}$

\section{Components of a Quality Online Course}

According to the focus group students, the components of a quality online course included (1) organization, (2) engaging presentation of course content, and (3) opportunities for assessment and professor feedback. This Section elaborates on each of these components below, sharing not only student quotes but also the reasons why students identified these

217. Focus Group 1, supra note 200, at 19-20 (Student 4). The student elaborated that he or she appreciated one professor in a $1 \mathrm{~L}$ class who was really great at posing hypotheticals to "draw out obscure doctrines that you're dealing with." Id. That interaction with the professor, the student stated, helped him or her apply the subject matter and get live in-person feedback. Id.

218. Id. at 3 (Student 4); see also Focus Group 3, supra note 199, at 4 (Student 1, stating that in online classes, you could not raise your hand to ask a question of the professor and that you "are just kind of stuck with what's on that paper or what's in that video").

219. Consistent with the student's point that he or she could email the professor in an online course with questions, another focus group student mentioned that the professors he or she had for online classes offered opportunities for the students to ask questions of the professor either via discussion posts or through virtual office hours. Focus Group 2, supra note 204, at 5 (Student 7).

220. Id. at 6 (Student 4).

221. The student said, "But I've also had classes that were more issues-based, I would say, where a lot of the learning process was in the discussion, and in the conversations back and forth, and I think it's possible to have those in the online classes. I've had that in online classes. I don't think it's particularly effective, and I don't think it's particularly conducive to learning." Id. at 7 (Student 8). 
components as being crucial for a course to engage them in the learning process.

Students stated that while organization was also important in live classes, an organized course presentation and clear signaling about expectations were critical to their ability to learn well in the online setting. One student said,

For me personally, like how much I've liked an online depends on how it was structured, because there's then some classes where sometimes I have two quizzes, sometimes I have four quizzes a week, sometimes I have a discussion, sometimes I don't, and then when you're notified of that really makes difference, so I think structure is a huge influence. $^{222}$

Another echoed that thought, stating,

I think a lot depends, as far as learning goes, depends on how the course is structured. Like, the first course I took, I put a lot of effort on my own part into it, but I also thought it was really well-structured as far as what was required each week and their explanations of what their expectations were for the assignments each week, and then their feedback for what you did. ${ }^{223}$

In terms of engaging presentation of course material, students highlighted the benefit of short videos that were focused on a particular topic. ${ }^{224}$ One student explained it this way,

But from what we know about the brain and the attention span, I think that those videos are particularly good for me because it was sort of a bite-size snapshot of this is what you can take in at this point in time. So, as opposed to a full two- or three-hour lecture, which is certainly hard to sit through. And, I think we drift in and out of that sometimes. ${ }^{225}$

Students consistently mentioned that long and uninspired lectures did not enhance their learning experience in the online environment. ${ }^{226}$ One student explained why shorter lectures were more helpful. Specifically, the student could "watch a 20 minute one, one day, and then a 30 minute one the next, and then maybe [he or she will] sit for 15 or whatever" for the

222. Id. at 13 (Student 5)

223. Focus Group 3, supra note 199, at 5 (Student 4).

224. See, e.g., Focus Group 1, supra note 200, at 6 (Student 1, stating that he or she found helpful "the short, very specific videos that either had supplemental material or a formative assessment that was directly on that").

225. Focus Group 3, supra note 199, at 5 (Student 3).

226. See, e.g., Focus Group 1, supra note 200, at 5 (Student 4: "One of the other classes that I felt I didn't learn the material as well was where the professor lectured for two and a half hours during the week in an online setting, and then had one of the formative assessments."); id. at 5 (Student 1, stating that the student just gave up and got the worst grade in his or her law school career in an online class where the professor "literally read from the textbook for two hours"). 
next video. ${ }^{227}$ In other words, "chunking" the videos makes it easier for students to do their work - they can watch short, focused videos on specific topics. ${ }^{228}$

In addition, students pointed to formative assessments as a feature of a quality online learning experience, noting how they provided them an opportunity for a weekly check-in on the learning process. ${ }^{229}$ Comments showed a particular fondness for regular quizzes to help students assess whether they were on track learning course material. ${ }^{230}$ As one student put it, "I would much prefer the online, ungraded weekly quizzes. Give me a 20 question quiz that I can just do to check to make sure that I'm understanding things." 231

Students also emphasized how the professor's use of practice-ready assignments in the online setting aided them in learning course material and helped them master practical skills. For example, one mentioned that online classes provided the opportunity to complete assignments similar to "an exam style question and doing substantive analysis work that in a live class, you might not do until you take the final." ${ }^{232}$ Another commented similarly, stating that in one online class, he or she had a "deliverable [that] could range to anything from a contract ... to an email sent to a client."233 The student emphasized how he or she appreciated this practice and how it differed from many live classes where the student only had the opportunity to read and answer a final exam question. ${ }^{234}$ The same student explained that practical assignments, such as writing a memo, helped with engagement and learning. This is because those types of assignments required the student to learn something and "then ... apply it to something that you will actually use or do in real life versus something that is all

227. Focus Group 2, supra note 204, at 14 (Student 6).

228. Another feature of engaging course content that students mentioned was supplementary learning material, such as the posting of relevant YouTube videos relating to course content. See, e.g., Focus Group 1, supra note 200, at 6 (Student 5, stating that he or she finds it helpful when professors put links to "[m]aybe a YouTube video or some sort of a clip" that helps drive home course content but that is "[not] necessarily from law school per se"); Focus Group 3, supra note 199, at 21 (Student 4: "But like if they find something on YouTube that they want us to look at. Yeah, just any kind of video is always good I feel like.").

229. See, e.g., Focus Group 1, supra note 200, at 4-5 (Student 4: "Those weekly check-ins I felt really helped me learn the material in the same way that people have talked about.").

230. See, e.g., id. at 6, 17 (Student 2, stating that "the weekly quizzes that I have had in some courses have forced me to pay more attention to the reading than I otherwise might, which is something you don't get in a live class" and that he or she "especially like[s] the quizzes that give you the answers as soon as you've submitted the quiz" because "you can also use that as learning material"); id. at 6 (Student 3, stating that he or she "always found [quizzes in online classes] helpful as far as making sure that I learned what I needed to learn").

231. Focus Group 2, supra note 204, at 16 (Student 6).

232. Focus Group 1, supra note 200, at 6 (Student 2). That same student also said that "in the online classes, professors are able to find more ways to assign practical assignments, like client emails or drafting of a court document or something like that." Id. at 9-10.

233. Id. at 6 (Student 3).

234. Id. 
based on theory." 235 Another said, "I think my personal growth and development in a lot of these online classes have been so much more substantial, just because of that time, being able to be spent doing practical [assignments]." 236

Moreover, students commented that having to do regular formative assessments made their online classes more valuable than many of their live courses in terms of their professional development. For example, one student said that having the regular assessments and "getting that feedback throughout the semester is something you don't get in $95 \%$ of the in-class courses here, and I think for me it has helped my learning and has solidified my understanding of the material in these classes, because I'm checking myself along the way."237 Another said that he or she finds live classes "to be a real waste of time, but in the online courses, it's a little different, because you have a lot of practice assignments or discussion boards or a vast amount of resources at your disposal." ${ }^{238}$ According to the student, these "practical" assignments in online classes "are so much more worthwhile than my ability to take a final exam [in a live class]." ${ }^{\text {"239 }}$ A different student made a similar comment, stating that he or she has really enjoyed the weekly assignments in online classes,

[B]ecause typically in a live course, you don't have graded assignments on a regular basis. You have one final at the end of the semester. The ungraded weekly assignments in some of these online courses are a really great way to test your knowledge of the material and identify weak points. $^{240}$

Other students made similar comments about the value of the regular assessments and feedback available to them in online classes as compared to some of the live classes they had taken in law school. ${ }^{241}$

Overall, students generally indicated that they would like to see more online programming. ${ }^{242}$ One student, in fact, stated that he or she would

\footnotetext{
235. Id. at 17 .

236. Focus Group 2, supra note 204, at 22 (Student 7).

237. Id. at 5 (Student 1).

238. Id. (Student 7).

239. Id.

240. Id. at 14 (Student 1).

241. See, e.g., id. at 6 (Student 5: "I feel like the online classes you have a better opportunity to apply the material you're learning throughout the semester, so it just gives you more of a chance to better learn it, and I feel more prepared for the final by the end."); $i d$. at 21 (Student 8: "I think some people really do benefit from that kind of more constant feedback [in the online classes]. I know that that's something that they're trying to integrate into some of the live classes.").

242. Students also generally stated that they believed they had taken quality online courses at the law school. See, e.g., Focus Group 3, supra note 199, at 27 (Student 1: "Yeah, I think they're good. I mean there's definitely some variation, but I think that overall, they're good."); $i d$. (Student 2: "With just like anything, there are areas that could be improved, but nothing's broken right now."); id. (Student 3, comparing the online experience in a Master's program to the IU McKinney online classes and stating, "I felt like ours were much more structured over here in McKinney, than I've seen in other formats.").
} 
have been willing to take half of his or her classes online. The student stated, "I think I would've learned just as well, but I wouldn't have been as stressed out because of the flexibility." ${ }^{243}$ Others echoed that they would have taken more online classes had they been offered. ${ }^{244}$ Another student came back to the role that the professor plays in the online classroom setting, stating that if the same professor was offering the same class live and online, the student would prefer to take the online class because it would allow the student to work or do internships. ${ }^{245}$ However, the student would not choose an online class solely for the flexibility it offered. ${ }^{246}$ Students did note that they did not think the law school environment would benefit from having all classes online because students liked the opportunity to engage with both fellow students and professors in the law school building. ${ }^{247}$

Thus, the data from the focus groups is consistent with the results of some other studies on online learning in both the undergraduate or graduate setting. Elements of online instruction that students appreciate include respectful faculty, ${ }^{248}$ substantial interpersonal communications, ${ }^{249}$ an ability to easily share information ${ }^{250}$ and ask questions, ${ }^{251}$ flexibility in learning the material, ${ }^{252}$ and a course design that keeps students from falling behind. ${ }^{253}$ Most importantly, the value of an online course, and how it is perceived by students, depends on the professor's ability to engage with the students over the Internet while remaining physically separated from the students. For example, Professor Lynn Clouder et al. found that when group interactions shifted from a face-to-face setting to an asynchronous online setting, the role of the online facilitator "cannot be underestimated" and that the professor serves "as a central feature of the model and a link from one context to the other." 254

\footnotetext{
243. Focus Group 1, supra note 200, at 19 (Student 2).

244. See, e.g., Focus Group 2, supra note 204, at 20 (Student 5: "I think just having more online classes would be really helpful."); id. (Student 6: "I would've taken more, had I been able to.").

245. Focus Group 3, supra note 199, at 16-17 (Student 1).

246. Id. (Student 1: "If I'm choosing between the same ... professor, same class? I would do online.").

247. See, e.g., id. at 23 (Student 1: "I think that if we put too much online, we're kind of eliminating some of those opportunities that could present themselves just [by] physically, not paying attention, but just by physically being in class at all."); id. (Student 2: "Maybe it's just the socializing thing, but I think that's important. And putting too many classes online I think could jeopardize the environment we're trying to keep up.").

248. Bergstrand \& Savage, supra note 190, at 294.

249. Id. at 296.

250. Tutty \& Klein, supra note 190 , at 118

251. Porter et al., supra note 56, at 8.

252. Id.

253. Id.

254. Lynn Clouder et al., Electronic [Re]constitution of Groups: Group Dynamics from Faceto-Face to an Online Setting, 1 INT'L J. COMPUTER-SUPPORTED COLLABORATIVE LEARNING 467, 479 (2006).
} 


\section{CONCLUSION}

The research data from the IU McKinney study shows that law students can be just as engaged and learn just as much, if not more, in an online course as a traditional classroom. The data shows that for these results to be possible, an online course and the professor running it must be organized, offer engaging content and lectures, and provide multiple opportunities for course assessment and professor feedback. ${ }^{255}$ While the students in our surveys and focus groups are generally positively inclined toward online teaching and learning, this does not mean that every graduate or undergraduate student will embrace the online environment.

First, the students in the focus groups consistently stated that they believed that the students who do best in the online environment are those who are self-disciplined and focused on learning. ${ }^{256}$ This conclusion by the student participants is consistent with the literature that shows that maturity and self-regulation play a role in whether one is motivated in the online environment. ${ }^{257}$ Much of the literature suggests that students with high levels of self-regulation and discipline are most likely to succeed in the online environment, where they must self-direct their learning process. $^{258}$ One study shows that students believe that to succeed in online courses, they must have high levels of personal responsibility and good

255. See supra Part IV.

256. See, e.g., Focus Group 1, supra note 200, at 12 (Student 1: "I think if you're self-disciplined, online classes are really good for you. You're very good at making yourself do the work and everything. Even if there's not a professor there watching or calling you out, if you're self-disciplined enough to do everything you're supposed to, then yeah. I think online classes is an easier choice for you."); id. at 15 (Student 3, stating that he or she would tell self-disciplined students to take online classes because " $[\mathrm{t}]$ hey will probably get more out of it versus in an in-classroom setting. They're learning more than what you would normally learn in the classroom versus somebody that's not disciplined."); Focus Group 2, supra note 204, at 10 (Student 7, stating that to succeed in an online class, "it kind of takes somebody that kind of stays on top of things to really be able to get involved and engaged and stay on top of it"); Focus Group 3, supra note 199, at 10 (Student 1, stating that for online classes, students need to "be really focused" and admitting that he or she is "not the most focused person on this planet or in this room").

257. See Di Xu \& Shanna S. Jaggars, Performance Gaps Between Online and Face-to-Face Courses: Differences Across Types of Students and Academic Subject Areas, 85 J. HIGHER EDUC. 633, 634 (2014) (stating that students at all levels who are successful in self-regulation and self-discipline are also more likely to be successful in an online course).

258. See Roger Azevedo et al., Does Adaptive Scaffolding Facilitate Students'Ability to Regulate Their Learning with Hypermedia?, 29 CONTEMP. EDUC. PSYCHOL. 344, 362 (2004) (finding that students who engaged in self-regulating processes and strategies in a hypermedia environment performed better than those who used less or no self-regulation); Lynch \& Dembo, supra note 22, at 10 (finding that "there is a significant and positive relationship . . . between self-efficacy and performance in online education"); Cherng-Jyh Yen \& Simon Liu, Learner Autonomy as a Predictor of Course Success and Final Grades in Community College Online Courses, 41 J. EdUC. Computing Res. 347, 356 (2009) (finding that "[s]tudents with higher learner autonomy are more likely to complete a community college online course with higher final grades"); $c f$. Barnard et al., supra note 22 (finding that "[o]nline self-regulatory learning behaviors were only weakly associated with better academic achievement by themselves" and self-regulation works best when combined with online communication and collaboration). 
time-management skills. ${ }^{259}$ One might expect that, on the whole, law students and other graduate students are more likely than undergraduate students to be self-disciplined. ${ }^{260}$ Research also indicates that while the motivations for positive self-regulation may differ from student to student, it is important that professors who have positively self-regulated students provide an environment and activities that do not defeat that self-regulation. ${ }^{261}$

However, the research data also shows that even the students who prefer online courses for any number of reasons, and would self-select into an online course over a traditional face-to-face course, want those online courses to meet or exceed a traditional classroom's quality. ${ }^{262}$ Some best practices for online teaching that those students are looking for include an organized structure and content flow, engaging lectures, materials that connect the content to the "real world," and assignments that allow students to check their understanding of the material and that are practical for when they graduate law school. ${ }^{263}$ Furthermore, they are looking for courses where the professor is not compensating for the lack of direct contact by assigning work above and beyond what would be required in a similar credit hour traditional classroom. ${ }^{264}$ Instead, they want a realistic amount of work and the professor to engage them through lectures and other content, including useful practice-ready assignments on which they can receive feedback. ${ }^{265}$

The ABA's slow acceptance of online courses in law schools means that online teaching for many law professors is a new experience and a difficult balancing act, requiring them to abide by the ABA's mandate that

259. Rachel Hare Bork \& Zawadi Rucks-Ahidiana, Role Ambiguity in Online Courses: An Analysis of Student and Instructor Expectations 1, 11 (Cmty. Coll. Research Ctr., Working Paper No. 64, 2013) (reporting that students "stressed the idea that responsibility and motivation are essential driving forces behind successful online course outcomes").

260. Artino \& Stephens, supra note 22 (stating that "graduate students ... were more likely to report lower levels of procrastination"); Shea et al., supra note 95, at 541 (noting that "[a]dult graduate students, compared to undergraduates and younger students, possess different learning approaches, take greater ownership over their learning, and possess a bigger cache of experience that they bring to the educational setting"); cf. William Y. Lan, The Effects of Self-Monitoring on Students' Course Performance, Use of Learning Strategies, Attitude, Self-Judgment Ability, and Knowledge Representation, 64 J. EXPERIMENTAL EDUC. 101, 113 (1996) (stating that "even graduate students, the experienced veterans of higher education, need assistance in engaging self-monitoring processes to improve their learning"); Peter E. Williams \& Chan M. Hellman, Differences in Self-Regulation for Online Learning Between First- and Second-Generation College Students, 45 RES. HiGHER EDUC. 71, 77-78 (2004) (stating that first-generation college students are more likely to be less self-regulated in the online environment and those students are "more likely to be older [and] to be married with dependents").

261. Scott G. Paris \& Alison H. Paris, Classroom Applications of Research on Self-Regulated Learning, 36 EDUC. PSYCHOLOGIST 89, 98 (2001) (providing the example that "if a student has failed high-stakes multiple-choice tests for several years, he or she might feel pessimistic, helpless, or angry when given another such test" and might act deliberately "[t]o avoid another threat to self-esteem or potential confirmation of low ability" by missing class or not putting forth $100 \%$ effort).

262. See supra Part IV.

263. See supra Part IV.

264. See supra Part IV.

265. See supra Part IV. 
interactions be similar to those of a traditional classroom while also meeting student expectations of quality course. As more law professors and administrations expand their online course catalogs, the student perception data in this Article can be a helpful guide on how to structure these online courses to ensure that students are both engaged and learning in the asynchronous online environment.

\section{APPENDIX A}

\section{FOCUS GROUP GUIDE: ASSESSING STUDENT ENGAGEMENT AND LEARNING IN LAW SCHOOL ONLINE COURSES}

\section{A. Preliminary Comments}

Mr. Jerolimov will introduce himself and Ms. Long. He will provide potential subjects with the informed consent document. He will provide time to read the document and ask questions. He will answer any questions. He will collect all signed consent forms before beginning the FG session. Any student not wishing to participate after reading the consent form will be excused.

After consent forms have been collected and any potential subjects excused, Mr. Jerolimov will briefly explain the mechanics of the FG session. Namely, he will serve as the moderator posing questions that should be used to prompt conversation among the FG participants. This is not an interview; the goal is to stimulate interaction and thinking among the participants.

Mr. Jerolimov will also remind participants that he and Ms. Long will keep their identities and comments during the session confidential. He will also ask that participants not share information that occurred during the session with others so that everyone can feel confident in speaking freely.

\section{B. Introductions of FG Participants}

Mr. Jerolimov will explain that participants will not be identified in any publications based on this research, nor be identified to Professors Dutton and Ryznar. Nevertheless, Mr. Jerolimov will ask participants to identify themselves by name so that Mr. Jerolimov and Ms. Long may keep records of the session. To ensure that participants meet the criteria for the study, he will also ask participants to state how many online courses they have taken at IU McKinney and when they took those courses.

1. What is your name?

2. How many online courses have you taken at IU McKinney?

3. During what year or years did you take online courses at IU McKinney? 


\section{Online Versus Live for Student Engagement and Learning: Launch Questions to Stimulate Conversation and Interaction}

Before posing specific questions, Mr. Jerolimov will remind participants that the research does not require them to name particular professors and courses and that their comments can be more general in nature.

He will also inform participants that their responses are neither right nor wrong; participants can also disagree with views expressed by other participants.

1. You have all taken at least one online class at IU McKinney and many live classes. How do you compare the online experience to the live experience in terms of student engagement - being engaged in learning the course material? Be specific. (Again, there is no need to mention names or courses. You could mention types of activities in online or live classes that you feel do or do not enhance student engagement with the material instead.)

2. You have all taken at least one online class at IU McKinney and many live classes. How do you compare the online experience to the live experience in terms of student learning - actually learning the course material? Do you feel students learn more or less in one environment or the other? Be specific about what learning was (or was not) improved, and why you think it was (or was not) improved. (Again, there is no need to mention names or courses. You could mention types of activities in online or live classes that you feel do or do not enhance student engagement with the material instead.)

3. As students who have taken one or more online classes at IU McKinney, do you have any views about whether the school's online classes are more or less rigorous (however you wish to define that term) than the live classes at IU McKinney?

4. As students who have taken one or more online classes at IU McKinney, do you have any views about whether particular types of students benefit more or less from online or live classes in terms of student engagement or learning?

D. Online Programming Generally: Launch Questions to Stimulate Conversation and Interaction

1. As students who have taken one or more online classes at IU McKinney, do you have views as to the primary reasons why law students at this school may wish to take a class online-as opposed to live?

2. As students who have taken one or more online classes at IU McKinney, would you recommend that students take online classes at the law school? Why or why not? Be specific. 
E. Strengthening Online Programming Generally: Launch Questions to Stimulate Conversation and Interaction

1. As students who have taken one or more online classes at IU McKinney, what advice would you share to help make that programming as strong as possible in terms of engaging students and enhancing student learning of material? In particular, are there any specific activities or teaching methods that you believe are particularly helpful to student engagement and learning in the online learning environment?

2. As students who have taken one or more online classes at IU McKinney, do you believe law students could benefit from more online programming? Why or why not? Be specific.

3. Students in online courses do the work on their own time. As students who have taken one or more online classes, how were you motivated to do the work? Were you self-motivated? Or did the course structure or activities motivate you to do the work and learn the course material?

F. Overall Conclusion About IU McKinney Online Programming:

Launch Questions to Stimulate Conversation and Interaction

1. Overall, what is your assessment of the quality of IU McKinney's online programming? Give reasons why you conclude as you do.

G. Open-Ended

1. Anything else you would like to share about IU McKinney's online programming as regards student engagement and learning?

2. Any other recommendations about the online programming at IU McKinney? (E.g., more courses online? More of some types of courses online? More courses during the summer or not? Why?) 